Check for updates

Cite this: RSC Adv., 2020, 10, 7265

Received 27th January 2020

Accepted 10th February 2020

DOI: 10.1039/d0ra01140a

rsc.li/rsc-advances

\title{
Facile approach to benzo[d]imidazole-pyrrolo[1,2- a]pyrazine hybrid structures through double cyclodehydration and aromatization and their unique optical properties with blue emission $\dagger$
}

\begin{abstract}
Gi Hun Bae, $\$^{\mathrm{a}}$ Suzi Kim, $\$^{\mathrm{b}} \mathrm{Na}$ Keum Lee, ${ }^{\mathrm{b}}$ Anuradha Dagar, ${ }^{a}$ Jeong Hwa Lee, ${ }^{a}$ Jeeyeon Lee (D) ${ }^{* b}$ and Ikyon Kim (D) *a

A modular approach to polycyclic $\mathrm{N}$-fused heteroaromatics is described. Acid-catalyzed reactions of various 1-(2-oxo-2-arylethyl)-1H-pyrrole-2-carbaldehydes with several o-phenylenediamines provided facile access to a number of new benzo[d]imidazole-pyrrolo[1,2-a]pyrazine hybrid structures through double cyclodehydration and aromatization. Optical characterization of the synthesized compounds revealed unique emission properties, with deep blue emission in the aggregated and solid states, and a dramatic substituent effect was observed. Fusion of an additional benzene ring into the benzo[4,5] imidazo[1,2-a]pyrrolo[2,1-c]pyrazine scaffold resulted in a remarkable increase in the intensity of blue fluorescence from the solution along with good cell permeability and negligible phototoxicity, indicating the potential for bioimaging applications.
\end{abstract}

\section{Introduction}

Novel organic fluorophores are critical tools in biomedical research and play an important role in disease diagnosis and bioimaging applications. ${ }^{\mathbf{1 - 4}}$ Due to the detrimental aggregationcaused quenching (ACQ) effects of conventional fluorophores, various approaches to achieve stable and efficient emission have been explored.5,6 Along this line, aggregation-induced emission (AIE) and aggregation-induced emission enhancement (AIEE) have drawn much attention recently, as dramatic enhancements of emission in the aggregated or solid state have been observed. ${ }^{7-9}$ Although AIE luminogens have shown the potential to prevent quenching at high concentrations or in the solid state, practical issues remain, such as solubility and cell permeability, which need to be overcome to facilitate practical applications, particularly in various bioassays. ${ }^{6}$ Furthermore, the AIE effect has challenged our current understanding of the photophysical properties of photoluminescence. Therefore,

\footnotetext{
${ }^{a}$ College of Pharmacy, Yonsei Institute of Pharmaceutical Sciences, Yonsei University, 85 Songdogwahak-ro, Yeonsu-gu, Incheon, 21983, Republic of Korea. E-mail: ikyonkim@yonsei.ac.kr; Fax: +82 32749 4105; Tel: +82 327494515

${ }^{b}$ College of Pharmacy, Research Institute of Pharmaceutical Sciences, Seoul National University, 1 Gwanak-ro, Gwanak-gu, Seoul, 08826, Republic of Korea. E-mail: jyleeut@snu.ac.kr; Fax: +82 2884 8334; Tel: +8228802471

$\dagger$ Electronic supplementary information (ESI) available: ${ }^{1} \mathrm{H}$ and ${ }^{13} \mathrm{C}$ NMR spectra of synthesized compounds and CIF files for 8c. CCDC 1919367. For ESI and crystallographic data in CIF or other electronic format see DOI: 10.1039/dora01140a

\$ These authors contributed equally.
}

novel fluorophores with unique photophysical features are of great significance in practical applications. Blue or deep-blue emissive materials are particularly valuable in organic lightemitting diodes (OLEDs), but good blue or deep-blue emitters (AIEgens) are still rare due to their wide energy gaps. ${ }^{\mathbf{1 0 - 1 3}}$

Among the approaches reported to date, combinatorial synthesis approaches with high content imaging screening systems have shown great advantages to effectively accelerate the development of novel emissive materials, since the context of the cellular system is unpredictable in terms of the permeability, photostability and cytotoxicity of fluorophores. ${ }^{\mathbf{1 4 , 1 5}}$

Nitrogen-fused heterocycles are an important structural motif frequently found in a number of natural products, pharmaceuticals, and dyes. Among them, a number of $\mathrm{N}$-fused 5,6-ring systems, such as imidazo[1,2- $a]$ pyridine,${ }^{16}$ indolizine, ${ }^{17}$ and pyrazolo[1,5- $\left.a\right]$ pyrimidine,$^{18}$ have received much attention, as shown in Fig. 1.

Accordingly, numerous synthetic methods for these scaffolds have been well established, including ring annulation and intermolecular cross-coupling. ${ }^{19-22}$ Although a number of medicinal agents based on pyrrolo[1,2-a]pyrazine, another N-fused heterobicyclic system, have been disclosed in the literature, synthetic approaches to prepare this scaffold have been relatively underdeveloped, which prompted us to investigate the chemistry of pyrrolo $[1,2-a]$ pyrazine. In this context, we have been involved in the design and synthesis of new chemical spaces based on the pyrrolo[1,2-a] pyrazine core (Scheme 1). As a means to decorate the basic skeleton via intermolecular cross-coupling reactions, we have studied Pdcatalyzed direct (hetero)arylation ${ }^{23,24}$ and electrophilic acetylation/ formylation $^{25,26}$ of various pyrrolo[1,2-a]pyrazines (2), which were 
<smiles>Cc1ccc(-c2nc3ccc(C)cn3c2CC(=O)N(C)C)cc1</smiles>

zolpidem<smiles>CC[C@]1(O)C(=O)OCc2c1cc1n(c2=O)Cc2nc3ccccc3c(CCNC(C)C)c2-1</smiles>

belotecan<smiles>CCN(C(C)=O)c1cccc(-c2ccnc3c(C#N)cnn23)c1</smiles>

zaleplon

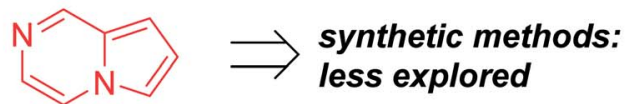

pyrrolo[1,2-a]pyrazine

Fig. 1 Nitrogen-fused heteroaromatics.

easily prepared by double cyclodehydration of $\mathbf{1}$ in the presence of $\mathrm{NH}_{4} \mathrm{OAc}$ (Scheme 1a). More recently, we have developed atomeconomical synthetic routes to prepare novel pyrrolo[1,2- $a]$ pyrazine derivatives (6-7) from 5 via tandem ring cyclization sequences (Scheme 1b). ${ }^{27}$ Ammonium acetate was used as an amine source for 2, 6, and 7. As an extension, we hypothesized that $o$ - phenylenediamine might be employed in the reaction with $\mathbf{5}$ as an alternative amine source, leading to pyrrolo[1,2-a]pyrazine-fused polycyclic heteroaromatic compound 8 (Scheme 1c). There is only one literature example, by Nagarajan and coworkers, on the synthesis of this heterocyclic core in which $\mathrm{N}$-propargyl-substituted pyrrole-2-carboxaldehydes were used under $\mathrm{Cu}$ catalysis. ${ }^{28}$ While

(a) intermolecular coupling<smiles>[R]C(=O)Cn1cc(C(N)=O)cc1C(N)=O</smiles>

(b) ring construction<smiles>[R]c1cn2cc(C(=O)O[Na])cc2c([R])n1</smiles><smiles>[R]c1cn2c([Al])ccc2c([R])n1</smiles>
3

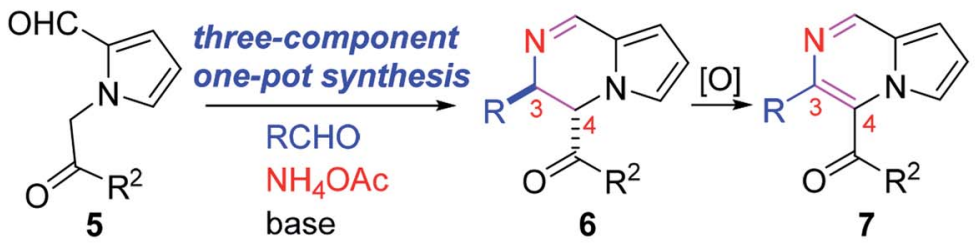

(c) novel polycyclic $\mathrm{N}$-fused heteroaromatics (this work)

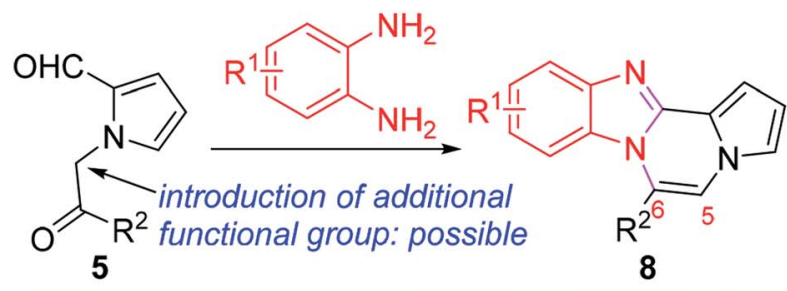

benzo[d]imidazole-pyrrolo[1,2-a]pyrazine hybrid via double dehydrative cyclization-aromatization

Scheme 1 Synthetic approaches to $N$-fused heterocycles. 


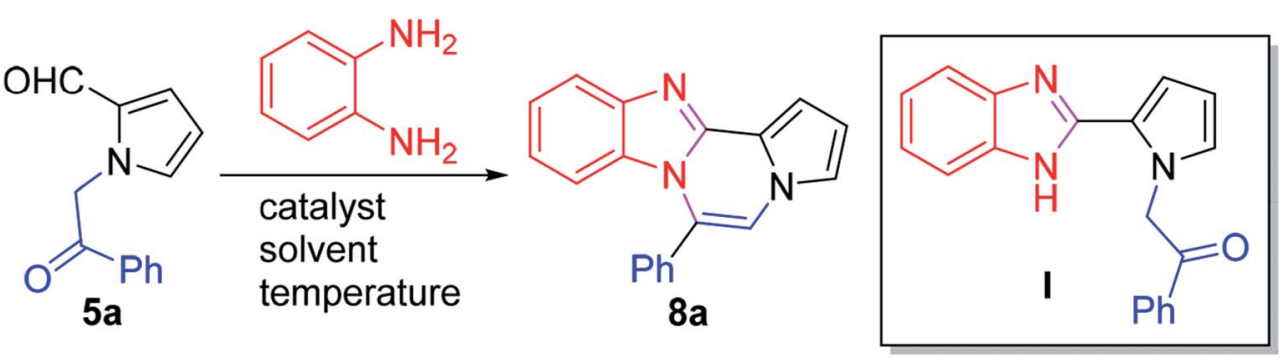

\begin{tabular}{|c|c|c|c|c|}
\hline Entry & Catalyst (equiv.) & Solvent & Temperature $\left({ }^{\circ} \mathrm{C}\right)$ & Yield $^{b}(\%)$ \\
\hline 1 & - & $\mathrm{AcOH}$ & 90 & 54 \\
\hline 2 & - & AcOH/toluene $(1: 1)$ & 90 & 55 \\
\hline 4 & DBSA (0.1) & Toluene & 130 & 63 \\
\hline 5 & PTSA (0.1) & Toluene & 130 & 62 \\
\hline 6 & $\operatorname{In}(\mathrm{OTf})_{3}(0.1)$ & DCE & 90 & 47 \\
\hline $9^{c}$ & TFA $(0.3)$ & DMSO & rt to 65 & 80 \\
\hline
\end{tabular}

${ }^{a}$ A mixture of $5 \mathrm{a}(0.188 \mathrm{mmol})$ and $o$-phenylenediamine $(0.244 \mathrm{mmol}, 1.3$ equiv. $)$ in solvent $(1 \mathrm{~mL})$ was stirred at the indicated temperature for $12 \mathrm{~h}$. The reaction mixture was stirred at $\mathrm{rt}$ for $16 \mathrm{~h} .{ }^{b}$ Isolated yield (\%). ${ }^{c}$ After a mixture of $5(0.188 \mathrm{mmol})$ and $o$-phenylenediamine (0.244 mmol, $1.3 \mathrm{equiv}$.) in TFA $\left(0.056 \mathrm{mmol}, 0.3\right.$ equiv.)/DMSO $(1 \mathrm{~mL})$ was stirred at $\mathrm{rt}$ for $8 \mathrm{~h}$, the reaction mixture was stirred at $65{ }^{\circ} \mathrm{C}$ for an additional $3 \mathrm{~h}$.

this method gave rise to the desired products with a methyl group at the C6 position, reactions with unsymmetrical o-phenylenediamines resulted in a mixture of regioisomers. Moreover, regioisomeric mixtures were obtained with arylpropargyl-substituted substrates as a result of incomplete isomerization. In contrast, our strategy could lead to the target skeleton with not only methyl but also various aryl moieties at the $\mathrm{C6}$ site, demonstrating versatility of our method. Since an additional functional group can be introduced to the $\alpha$ position of the ketone of our substrate 5 , we deemed that our approach to this skeleton would be more flexible, affording a wide variety of derivatives with substituent(s) at the C5 and/or C6 site(s). Mechanistically, dehydrative condensation of $o$-phenylenediamine with the aldehyde of $\mathbf{5}$ would form dihydrobenzo[ $d]$ imidazole, which would further react with other carbonyl moieties in $\mathbf{5}$ to give rise to tetracyclic compound $\mathbf{8}$ after air oxidation. Overall, we anticipated that a polycyclic heteroaromatic ring system would be constructed by a one-pot domino protocol consisting of double cyclodehydration and aromatization.

Furthermore, as we expected that the tetracyclic skeleton formed as a hybrid structure of benzo[ $d]$ imidazole and pyrrolo $[1,2-a]$ pyrazine, ${ }^{29-32}$ two versatile pharmacophores in medicinal chemistry, might exhibit intriguing photophysical properties, we decided to embark on the synthesis and optical characterization of this scaffold, which is described herein.

\section{Results and discussion}

\section{Design and synthesis}

The reaction was optimized with $\mathbf{5} \mathbf{a}^{33}$ and $o$-phenylenediamine (Table 1). Reactions in $\mathrm{AcOH}$ or $\mathrm{AcOH} /$ toluene $(1: 1)$ at $90{ }^{\circ} \mathrm{C}$ gave $8 \mathrm{a}$ in $54-55 \%$ yields (entries 1 and 2). While the use of DBSA (dodecylbenzenesulfonic acid) or PTSA as a catalyst improved the yield of 8a (entries 3-5), reactions in the presence of a Lewis acid furnished the product at a yield of $32-55 \%$ (entries 6-8). Finally, we were pleased to find that desired product 8 a was obtained in $80 \%$ yield by initial treatment of $5 \mathbf{a}$ and $o$-phenylenediamine in TFA/DMSO at room temperature for $8 \mathrm{~h}$ followed by warming at $65{ }^{\circ} \mathrm{C}$ for an additional $3 \mathrm{~h}$ (entry 9). ${ }^{34}$ The reaction in a closed vial gave similar results as that in open air. Intermediate I was identified at room temperature, and subsequent heating facilitated dehydrative cyclization to furnish 8a.

As shown in Table 2, reactions of 5a with several $o$-phenylenediamines were performed under optimized conditions to furnish the corresponding 6-arylbenzo[4,5]imidazo[1,2- $a]$ pyrrolo[2,1-c]pyrazines $(\mathbf{8 a - 8 g})$ in good to excellent yields. Notably, the use of unsymmetrical $o$-phenylenediamines such as 4 -fluoro- $o$-phenylenediamine and 4-chloro- $o$-phenylenediamine under these conditions gave rise to regioisomers $8 \mathbf{c}$ and $\mathbf{8 e}$, respectively. The structure of $\mathbf{8 c}$ was unambiguously confirmed by X-ray crystallographic analysis (CCDC number: 1919367, Fig. 2). 6-Phenylnaphtho $\left[2^{\prime}, 3^{\prime}: 4,5\right]$ imidazo $[1,2-a]$ pyrrolo $[2,1-c]$ pyrazine $(\mathbf{8 h})$ was obtained from the reaction with $2,3-$ diaminonaphthalene.

More diverse benzo[d]imidazole-pyrrolo[1,2- $a]$ pyrazine hybrids (8i-8ai) were synthesized with $\mathbf{5 b} \mathbf{b}$-i. The results are shown in Table 3, exhibiting a wide range of functional group tolerances under these reaction conditions. DBSA/toluene was used in some cases where TFA/DMSO afforded low chemical yields (8n, 8p, 8v, 8x, and 8y). 
Table 2 Synthesis of $8 \mathrm{a}-8 \mathrm{~h}^{a, b}$<smiles>[R17]c1ccc(N)c(N)c1</smiles>

$5 a$

$8 a-8 h$<smiles>c1ccc(-c2cn3cccc3c3nc4ccccc4n23)cc1</smiles>

8a (80)<smiles>Clc1cc2nc3c4cccn4cc(-c4ccccc4)n3c2cc1Cl</smiles>

8d (76)<smiles>Cc1cc2nc3c4cccn4cc(-c4ccccc4)n3c2cc1C</smiles>

8g (80)<smiles>Fc1cc2nc3c4cccn4cc(-c4ccccc4)n3c2cc1F</smiles>

$8 b$ (66)<smiles>Clc1ccc2c(c1)nc1c3cccn3cc(-c3ccccc3)n21</smiles>

8e (56)<smiles>c1ccc(-c2cn3cccc3c3nc4cc5ccccc5cc4n23)cc1</smiles>

8h (79)<smiles>Fc1ccc2c(c1)nc1c3cccn3cc(-c3ccccc3)n21</smiles>

8c (61)<smiles>Brc1cc2nc3c4cccn4cc(-c4ccccc4)n3c2cc1Br</smiles>

8f (62)

${ }^{a}$ After a mixture of $5 \mathrm{a}(0.188 \mathrm{mmol})$ and $o$-phenylenediamine $(0.244 \mathrm{mmol}, 1.3$ equiv. $)$ in TFA $(0.056 \mathrm{mmol}, 0.3$ equiv. $) / \mathrm{DMSO}(1 \mathrm{~mL})$ was stirred at $\mathrm{rt}$ for $8 \mathrm{~h}$, the reaction mixture was stirred at $65{ }^{\circ} \mathrm{C}$ for an additional $3 \mathrm{~h}^{b}{ }^{b}$ Isolated yield (\%).

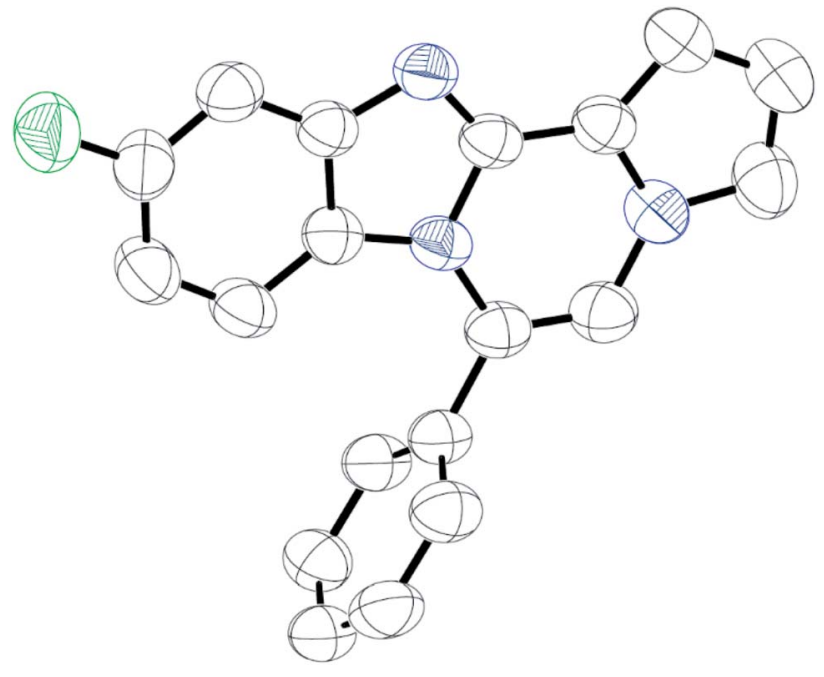

Fig. 2 Crystal structure of 8c.
The basic tetracyclic hybrid skeleton 9 was also obtained, although conversion of $\mathbf{5 g}$ to $\mathbf{9}$ required a higher reaction temperature (Scheme 2). When 10, derived from indole-2carbaldehyde, was allowed to react with $o$-phenylenediamine, the corresponding hexacyclic $\mathbf{1 1}$ was obtained in quantitative yield. As noted in the Introduction, benzo[ $d]$ imidazole-pyrrolo $[1,2-a]$ pyrazines 13a-b bearing two substituents at the C5 and C6 sites were constructed upon exposure of $\mathbf{1 2 a}-\mathbf{b}$ to the optimal reaction conditions, demonstrating the benefits of our protocol over the previous approach. In addition, further elaboration of the resulting $\mathbf{8 a}$ was conducted: $N$-alkylation of $\mathbf{8 a}$ with methyl iodide delivered the corresponding salt $\mathbf{1 4}$ in quantitative yield.

\section{Optical properties and structure-property relationship} analysis

We examined the optical properties of the synthesized compounds, as shown in Fig. 3 and Table S1. $\dagger$ The compounds exhibited absorption maxima at approximately 320-360 $\mathrm{nm}$ and emission 
Table 3 Synthesis of $8 \mathrm{i}-8 \mathrm{ai}^{a}$

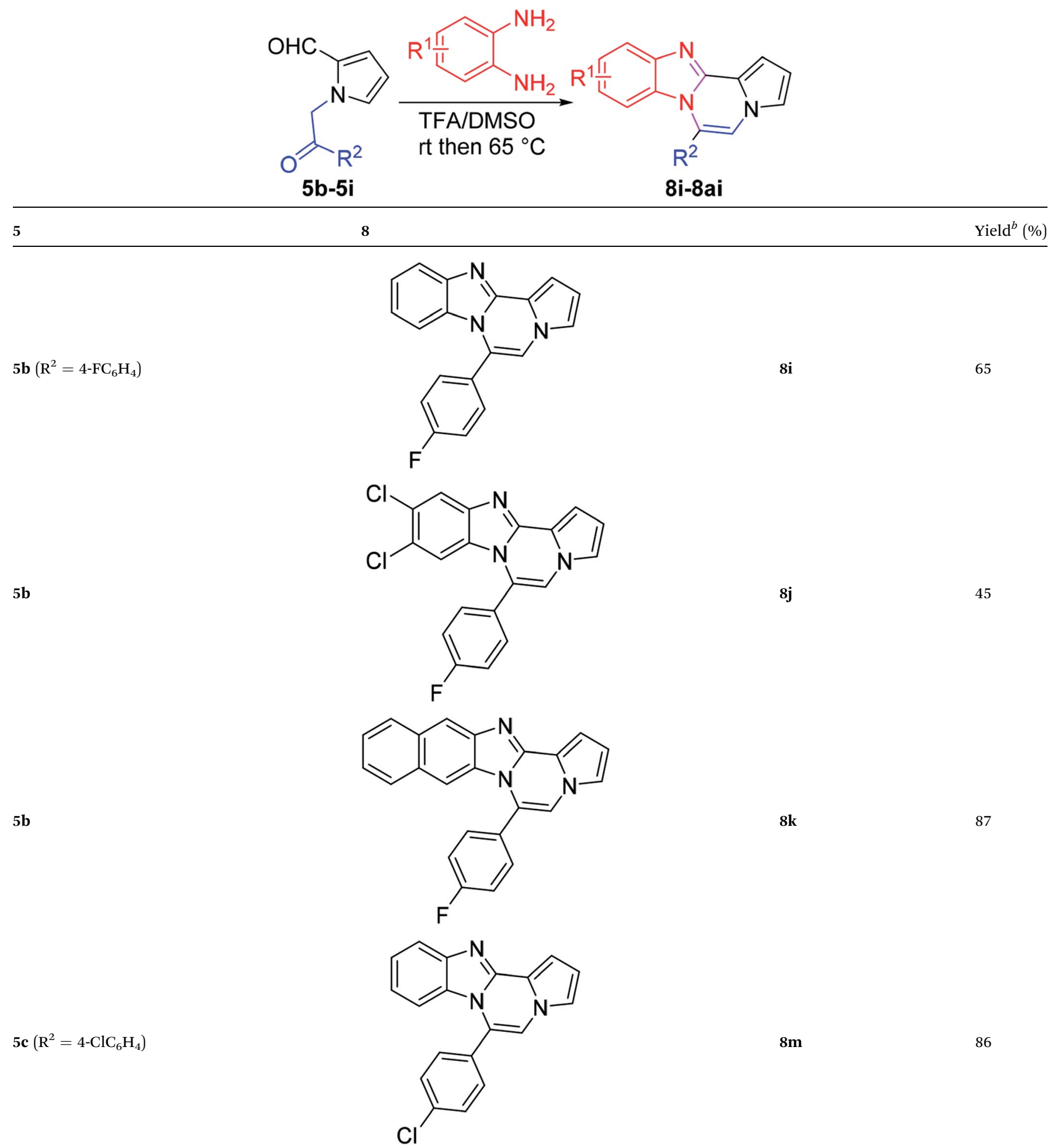


Table 3 (Contd.)

$5 c$

$5 c$

$5 c$

$5 c$<smiles>[R]C(=O)Cn1cccc1C=O</smiles>

$5 b-5 i$ 8i-8ai

5

8

$\operatorname{Yield}^{b}(\%)$<smiles>Fc1cc2nc3c4cccn4cc(-c4ccc(Cl)cc4)n3c2cc1F</smiles>

$8 n$

$70^{c}$<smiles>Clc1ccc(-c2cn3cccc3c3nc4cc(Cl)c(Cl)cc4n23)cc1</smiles>

80

81<smiles>Cc1cc2nc3c4cccn4cc(-c4ccc(Cl)cc4)n3c2cc1C</smiles>

$8 p$

$63^{c}$<smiles>Clc1ccc(-c2cn3cccc3c3nc4cc5ccccc5cc4n23)cc1</smiles>

$8 q$

72 
Table 3 (Contd.)

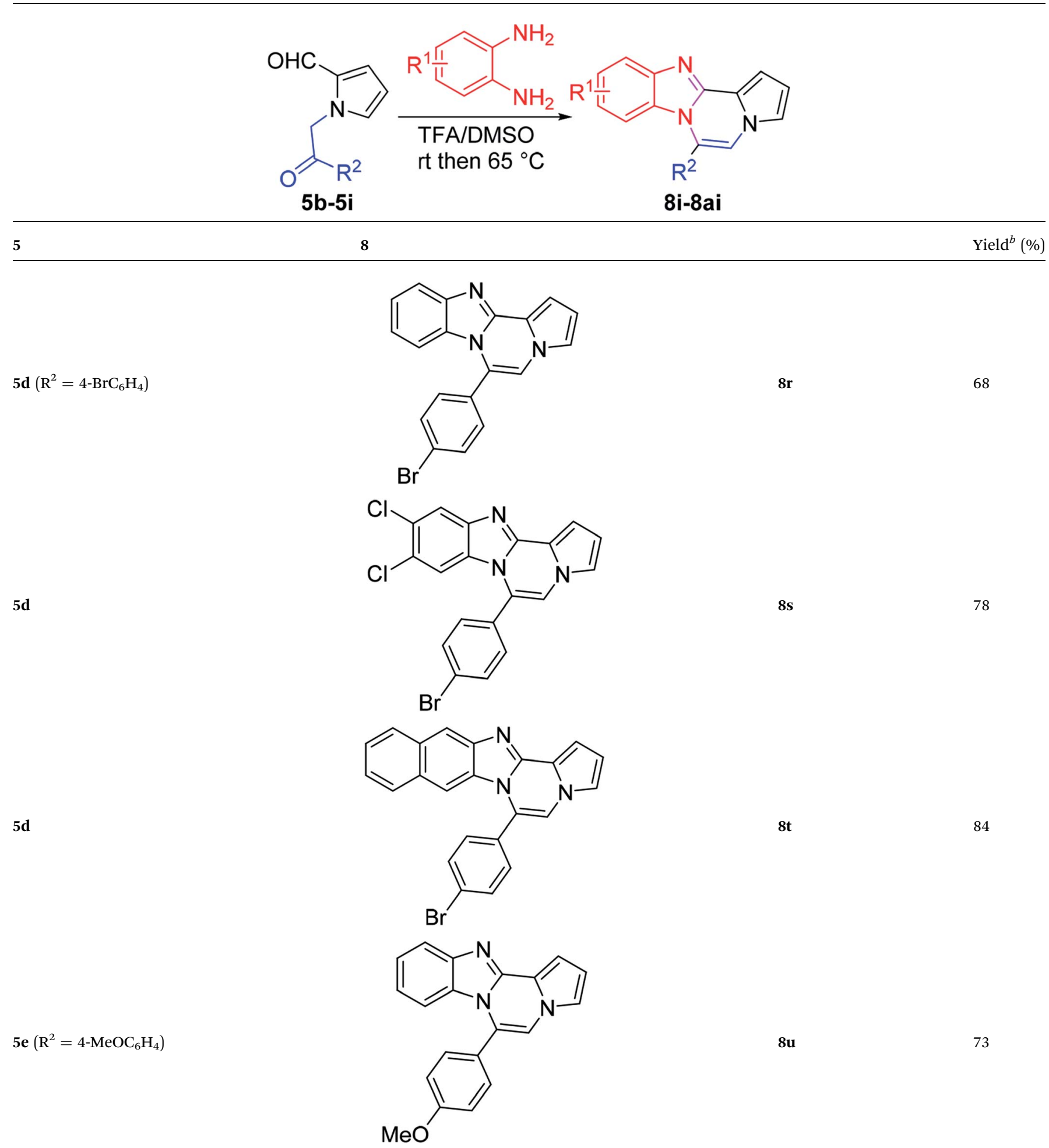


Table 3 (Contd.)<smiles>[R]C(=O)Cn1cccc1C=O</smiles>

$5 b-5 i$

8i-8ai

5

Yield $^{b}(\%)$

$5 e$<smiles>COc1ccc(-c2cn3cccc3c3nc4cc(F)c(F)cc4n23)cc1</smiles>

$8 \mathbf{v}$

$54^{c}$

$5 e$<smiles>COc1ccc(-c2cn3cccc3c3nc4cc(Cl)c(Cl)cc4n23)cc1</smiles>

$8 w$

91<smiles>COc1ccc(-c2cn3cccc3c3nc4cc(Br)c(Br)cc4n23)cc1</smiles><smiles>COc1ccc(-c2cn3cccc3c3nc4cc(C)c(C)cc4n23)cc1</smiles>

$8 \mathbf{8}$

$63^{c}$ 
Table 3 (Contd.)

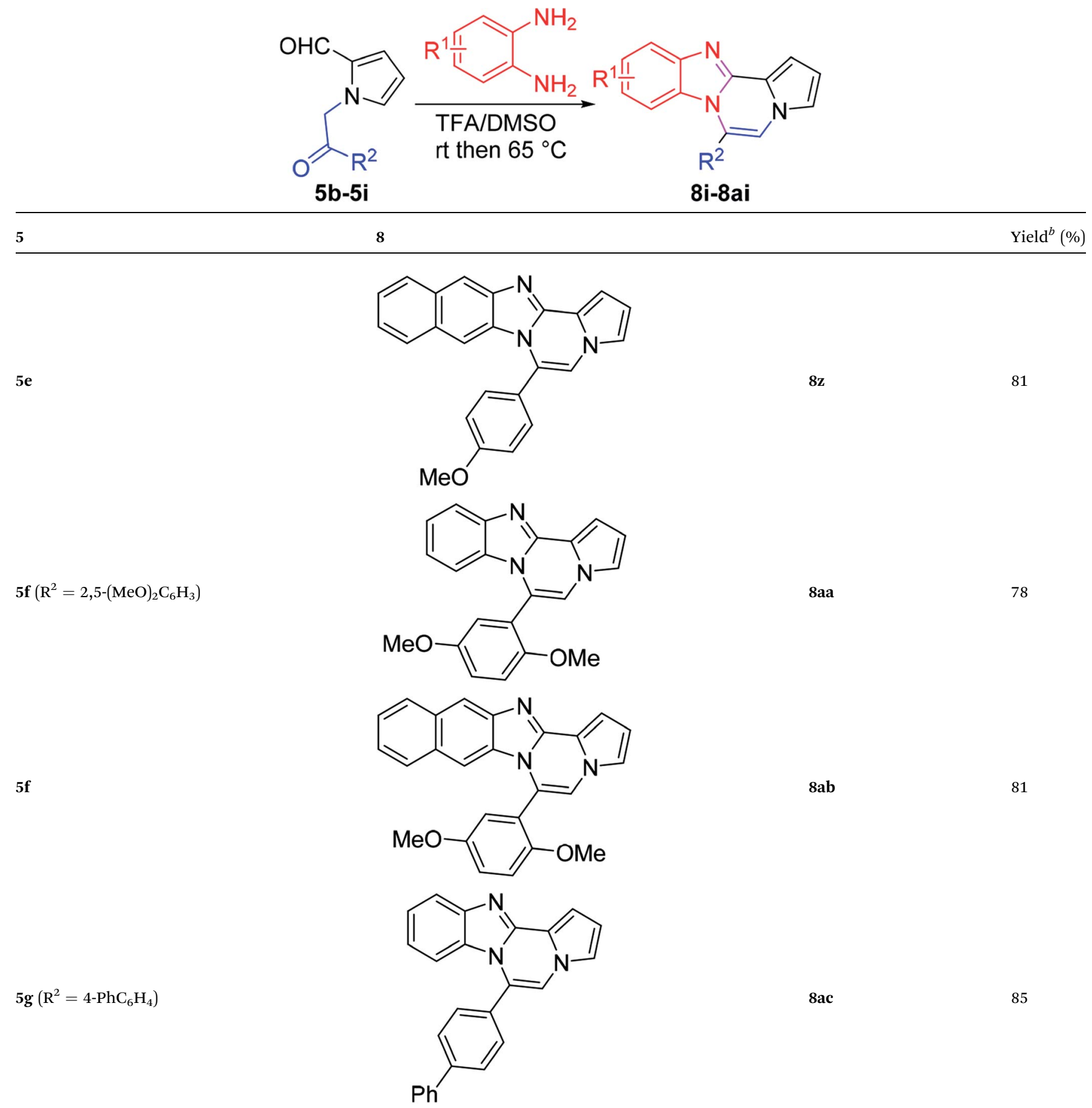


Table 3 (Contd.)<smiles>[R]C(=O)Cn1cccc1C=O</smiles>

$5 b-5 i$

8i-8ai

5

$5 g$

Yield $^{b}(\%)$<smiles>Clc1cc2nc3c4cccn4cc(-c4ccc(-c5ccccc5)cc4)n3c2cc1Cl</smiles>

8ad

58

$5 \mathrm{~g}$<smiles></smiles>

8ae

63

$\mathbf{5 h}\left(\mathrm{R}^{2}=2\right.$-naphthalene $)$<smiles>Clc1cc2nc3c4cccn4cc(-c4ccc5ccccc5c4)n3c2cc1Cl</smiles>

8af

$5 h$ 
$$
5 b-5 i
$$

$8 \mathrm{i}-8 \mathrm{ai}$

5

$5 h$

$5 \mathbf{i}\left(\mathrm{R}^{2}=\mathrm{Me}\right)$<smiles></smiles>

$8 a h$

8ai

79

80

\footnotetext{
${ }^{a}$ After a mixture of $5(0.188 \mathrm{mmol})$ and $o$-phenylenediamine $(0.244 \mathrm{mmol}, 1.3$ equiv. $)$ in TFA $(0.056 \mathrm{mmol}, 0.3 \mathrm{equiv}.) / \mathrm{DMSO}(1 \mathrm{~mL})$ was stirred at $\mathrm{rt}$ ( $0.244 \mathrm{mmol}, 1.3$ equiv.), and DBSA $\left(0.0188 \mathrm{mmol}, 0.1\right.$ equiv.) in toluene $(1 \mathrm{~mL})$ was stirred at $130{ }^{\circ} \mathrm{C}$ for $12 \mathrm{~h}$.
} for $8 \mathrm{~h}$, the reaction mixture was stirred at $65^{\circ} \mathrm{C}$ for an additional $3 \mathrm{~h} .{ }^{b}$ Isolated yield $(\%) .{ }^{c}$ After a mixture of $5(0.188 \mathrm{mmol}), o$-phenylenediamine
\end{abstract}$$
\begin{array}{ll}
\text { TFA/DMSO } \\
\mathrm{R}^{2} & \mathrm{rt} \text { then } 65^{\circ} \mathrm{C}
\end{array}
$$

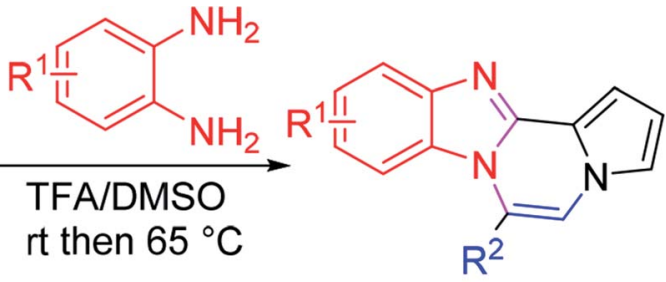

maxima at 400-450 $\mathrm{nm}$ in DMSO. Based on the optical properties, the compounds were categorized into two groups. Group A compounds possess a benzo[4,5]imidazo[1,2- $a]$ pyrrolo[2,1-c]pyrazine scaffold (named 4BP), whereas Group B compounds include 6-phenylnaphtho $\left[2^{\prime}, 3^{\prime}: 4,5\right]$ imidazo[1,2- $\left.a\right]$ pyrrolo[2,1-c]pyrazines and 7-phenylbenzo $\left[4^{\prime}, 5^{\prime}\right]$ imidazo $\left[2^{\prime}, 1^{\prime}: 3,4\right]$ pyrazino[1,2- $\left.a\right]$ indoles (named 5BP). Representative compounds are shown in Fig. 3 along with their absorption and emission spectra. In Group A, pyrrolo $[1,2-a]$ pyrazines without an aromatic ring at the C6 position showed strong blue emission in solution (8ai), but they were not emissive in the solid state due to the ACQ effect. The addition of benzene or naphthalene groups at the C6 position decreased the emission intensity, but the emission maxima were red-shifted (Table S1†).

Further structure-property relationship analysis revealed that the fluorescence intensity and emission maxima were significantly affected by attaching different substituents to the $\mathrm{R}^{1}$ and $\mathrm{R}^{2}$ positions of the benzo[4,5]imidazo[1,2- $\left.a\right]$ pyrrolo[2,1$c$ ]pyrazine scaffold (Fig. S1a $\dagger$ ). When attaching an electronwithdrawing halide to the $\mathrm{R}^{1}$ position (8d, Fig. $\mathrm{S} 1 \mathrm{~b}^{\dagger}$ ), the fluorescence intensity increased, and a hypsochromic shift was observed relative to $\mathbf{8 a}$ (Fig. S1a $\dagger$ ). However, by attaching an electron-donating $-\mathrm{CH}_{3}$ group to $\mathrm{R}^{1}$, as shown for $\mathbf{8 g}$ (Fig. S1c $\dagger$ ), the opposite effect occurred, that is, a bathochromic shift. 8m with $4-\mathrm{ClC}_{6} \mathrm{H}_{4}$ group at the $\mathrm{C} 6$ position (Fig. S1d $\dagger$ ) exhibited a slight bathochromic shift ( $\sim 10 \mathrm{~nm}$ ) compared to 8a, while $\mathbf{8 u}$ with $4-\mathrm{MeOC}_{6} \mathrm{H}_{4}$ group at $\mathrm{R}^{2}$ (Fig. S1e $\dagger$ ) showed blue-shifted emission with increased intensity. Overall, the electronic effect from the electron-withdrawing $\mathrm{R}^{1}$ and the electrondonating substituent on the phenyl ring of $\mathrm{R}^{2}$ was found to be important for enhancing the fluorescence intensity in Group A.

Extension with an additional benzene ring in Group B, which includes 6-phenylnaphtho[ $\left[2^{\prime}, 3^{\prime}: 4,5\right]$ imidazo[1,2-a]pyrrolo[2,1-c] pyrazines (8h) and 7-phenylbenzo[ $\left[4^{\prime}, 5^{\prime}\right]$ imidazo $\left[2^{\prime}, 1^{\prime}: 3,4\right]$ pyrazino[1,2-a]indole (11, Fig. $\mathrm{S} 2 \dagger)$, remarkably enhanced the fluorescence intensity compared to that from Group A.

\section{Aggregation induced blue-shifted emission from Group A}

Interestingly, $\mathbf{8 c}, \mathbf{8 g}$, and $\mathbf{8 i}$ showed an unusual hyposochromic shift in water. By increasing the water content in THF, blue-shifted emission at $362 \mathrm{~nm}$ was observed as the emission at $435 \mathrm{~nm}$ gradually decreased (Fig. 4a, b and S3 $\dagger$ ). As shown in Fig. 4c and d, the absorption and emission spectra of $\mathbf{8 g}$ were insensitive to solvent polarity. Therefore, the observed hyposochromic shift in aqueous solutions was suggested to be more related to the aggregated state emission. Indeed, the intensity of deep-blue emission at $362 \mathrm{~nm}$ in $95 \%$ water in THF solution increased by 12-fold 


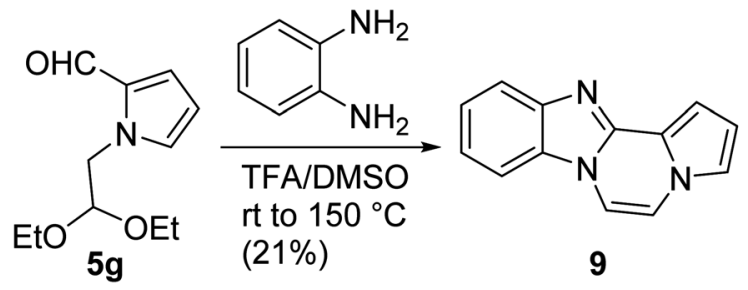

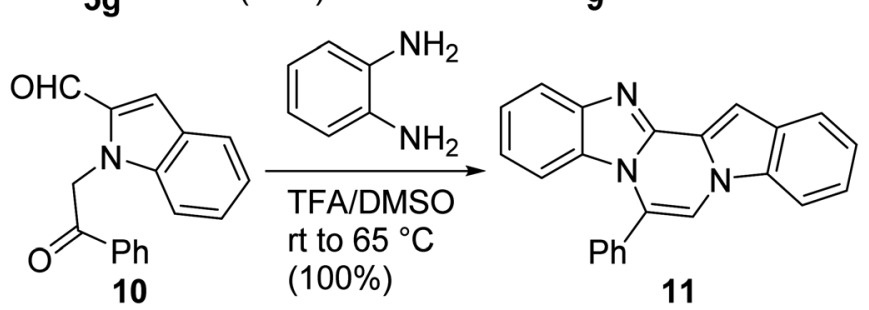<smiles>[R]c1c(-c2ccccc2)n2c3ccccc3nc2c2cccn12</smiles>

$12 \mathrm{a}(\mathrm{R}=\mathrm{Me})$

$12 b(R=B n)$

13a $(R=M e): 74 \%$

13b $(R=B n): 81 \%$<smiles>c1ccc(-c2cn3cccc3c3nc4ccccc4n23)cc1</smiles>

$8 a$

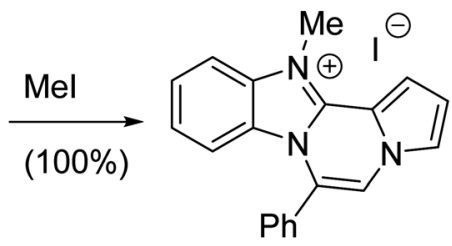

14
Scheme 2 Synthesis of 9, 11, 13, and 14 .

compared to that in a pure THF solution (Fig. $4 \mathrm{~b}$, inset). The observed blue shift was interesting since a bathochromic shift in the aggregated state is more common. ${ }^{35}$ With the addition of DMSO stock to water during sonication, moderately uniform nanoparticles were formed with a diameter of $198 \mathrm{~nm}$ (Fig. 5). Compared to the emission of $\mathbf{8 g}$ in DMSO, the emission of $\mathbf{8 g}$ as nanoparticles exhibited a significant blue shift by approximately $80 \mathrm{~nm}$.

\section{Bioimaging application with highly fluorescent 5BP series (Group B)}

5BP derivatives with an additional aromatic ring exhibited strong fluorescence intensity in solution, as shown in Table 4 . Their fluorescence quantum yields in solution were measured with anthracene $(\Phi=0.27 \mathrm{in} \mathrm{EtOH})$ as a standard and were as high as $56 \%$. 7-Phenylbenzo $\left[4^{\prime}, 5^{\prime}\right]$ imidazo $\left[2^{\prime}, 1^{\prime}: 3,4\right]$ pyrazino[ $[1,2-$ $a$ ]indole (11, Fig. S2d $\dagger$ ) showed comparable spectral features to 6-phenylnaphtho[ $\left[2^{\prime}, 3^{\prime}: 4,5\right]$ imidazo[1,2-a]pyrrolo[2,1-c]pyrazine (8h, Fig. S2a $\dagger$ ) but with a weaker intensity than that of $\mathbf{8 h}$.

The 5BP compounds were also tested for live cell imaging in HeLa cells using the Operetta high-content imaging system (Fig. 6). Extension with an additional aromatic ring in $\mathbf{8 h}, \mathbf{8 k}$, 8q, 8t, 8z, 8ab, 8ae, and 8ah showed bright blue fluorescence in the Operetta high-content screening system, demonstrating good cell permeability and potential for bioimaging applications. Meanwhile, extension with an additional benzene fused to the pyrrole side (11) did not induce significant cellular fluorescence. The phototoxicities of $\mathbf{8 a}, \mathbf{8 h}, \mathbf{8 z}$, and $\mathbf{1 1}$ were negligible in HeLa cells, as shown in Fig. S4. $\dagger$

\section{Solid state emission and XRD analysis}

As organic optoelectronic materials work in the solid state, the optical properties of BP scaffolds in the solid state were investigated and are summarized in Table 5. 8h and $\mathbf{1 1}$ exhibited significant red shifts of approximately $100 \mathrm{~nm}$ in their solidstate emission compared to those in solution, whereas $\mathbf{8 a}$ and $\mathbf{8 g}$ showed blue shifts in the solid state (Fig. 7).

Intrigued by different patterns of emission spectra induced by aggregation, we investigated the intermolecular interactions of $8 \mathrm{c}$ that contributed to the blue emission in the solid and nanoaggregated states. The geometry and packing arrangements were analyzed in crystal states using single-crystal X-ray diffraction (XRD) measurements (Fig. 8).

The single crystal of $\mathbf{8 c}$ was depicted as a monomer, two of which were paired in an anti-parallel alignment. Notably, the torsion angle between the phenyl group and benzo[4,5]imidazo [1,2-a]pyrrolo[2,1-c]pyrazine was $90.4^{\circ}$, suppressing the conjugation between the phenyl ring and $\mathrm{ABCD}$ ring (Fig. 8a). As shown in Fig. $8 \mathrm{~b}$ and $\mathrm{c}$, the molecules were arranged in an antiparallel mode and columnar stacked array with an intermolecular vertical distance of $3.58 \AA$ between two adjacent planes. Each assembled pair was separated from neighboring pairs with a contact distance of $5.09 \AA$ between the phenyl and pyrrole plane centroids (Fig. 8d). Between the antiparallel monomers, there were intermolecular $\mathrm{CH} \cdots \mathrm{N}$ interactions $(\mathrm{CH} \cdots \mathrm{N}$ bond: $2.56 \AA)$ with the phenyl ring and the nitrogen of the imidazole B ring (Fig. 8d), as shown by yellow lines. With the columnar stacked array, the intercolumnar contact between the imidazole (B ring) and fluorobenzene (A ring) formed intermolecular $\mathrm{CH} \cdots \mathrm{N}$ interactions of $2.58 \AA$, as shown by purple lines. Additionally, nonclassical hydrogen bonds of $\mathbf{8 c}$ ( $\mathrm{CH} \cdots \mathrm{F}$ bond: $2.73 \AA$ ) incorporated the intermolecular network, rigidifying the molecular conformation, which contributed to the aggregation-induced blue shift (Fig. 8d).

Generally, in the aggregated or solid state, the emission is redshifted by the geometry change in $\pi$-stacks from charge transfer or the formation of J-aggregates. ${ }^{36,37}$ On the other hand, solid emission at shorter wavelengths can be induced by modifying the linkage position of substituents, reducing the conjugation effect, or twisting the conformation..$^{11}$ In the case of $\mathbf{8 c}$, the observed blue-shifted emission was ascribed to the weakened intermolecular $\pi-\pi$ interactions due to the longer distance between two planes in the crystal packing. ${ }^{38}$ Conformational twisting and spatial restraint also inhibited planarization. Overall, with increasing distance, the conjugation degree was reduced, which caused a blue shift in the solid and nanoparticle states of $\mathbf{8 c}$.

\section{Conclusions}

In conclusion, a novel benzo[d]imidazole-pyrrolo[1,2-a]pyrazine hybrid system, benzo[4,5]imidazo[1,2-a]pyrrolo[2,1-c]pyrazine, 


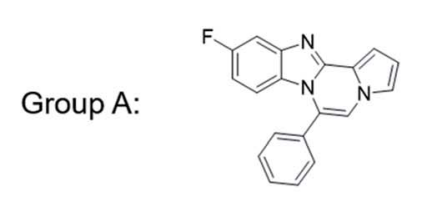

$8 \mathrm{c}$

$8 \mathrm{~h}$

(a)

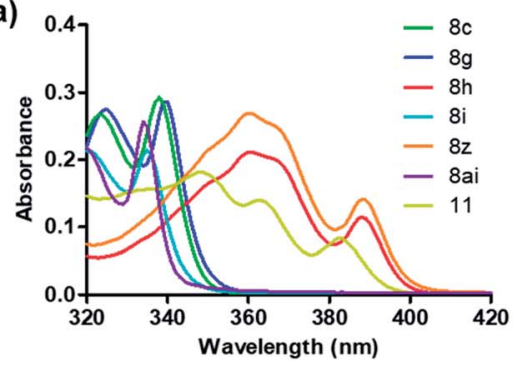

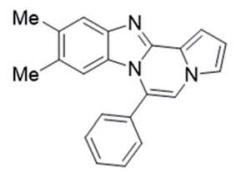

$8 g$

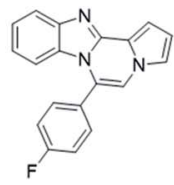

$8 \mathrm{i}$

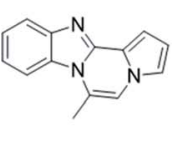

8 ai

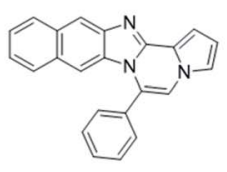

Group B:

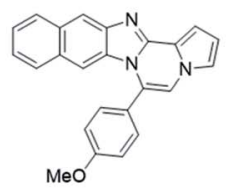

$8 z$

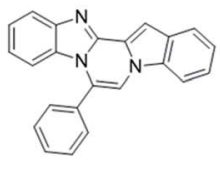

11 (b)

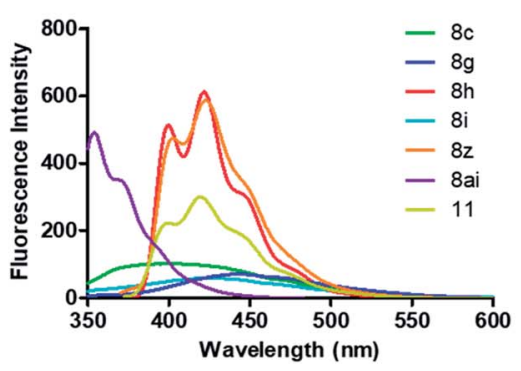

Fig. 3 Absorption spectra (a) of $10 \mu \mathrm{M}$ and emission spectra (b) of $1 \mu \mathrm{M} \mathrm{8c}, 8 \mathrm{~g}, 8 \mathrm{~h}, 8 \mathrm{i}, 8 \mathrm{z}, 8 \mathrm{ai}$, and 11 measured in DMSO.

was designed and synthesized via a cascade reaction consisting of double cyclodehydration and aromatization as part of our continued efforts to expand pyrrolo[1,2-a]pyrazine-based chemical space. A wide range of derivatives were readily accessed with high atom efficiency by this modular approach under mild reaction conditions. Optical characterization of the synthesized polycyclic $\mathrm{N}$-fused aromatics revealed that the fluorescence intensity and emission properties were significantly affected by attaching different substituents to the $\mathrm{R}^{1}$ and $\mathrm{R}^{2}$ positions of the benzo[4,5]imidazo[1,2-a]pyrrolo[2,1-c]pyrazine scaffold. Among the synthesized compounds, $\mathbf{8 c}, \mathbf{8 g}$, and $\mathbf{8 i}$ considerably showed aggregation-induced blue-shifted emission in the solid and nanoaggregated states, which would be valuable for organic lightemitting diode (OLED) applications. Fusion with an additional benzene ring into a benzo[4,5]imidazo[1,2-a]pyrrolo[2,1-c]pyrazine scaffold resulted in a remarkable increase in blue (a)

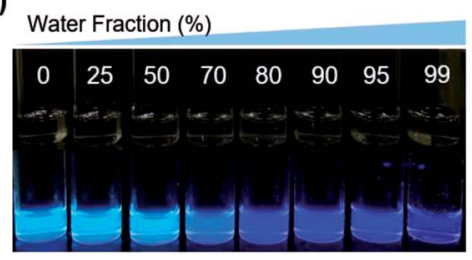

(c)

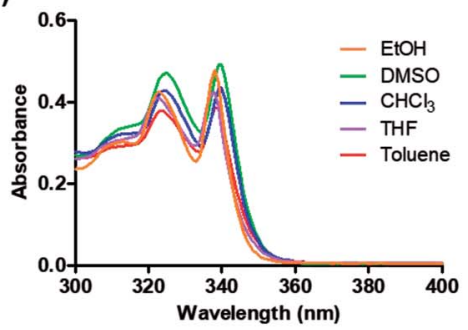

(b)

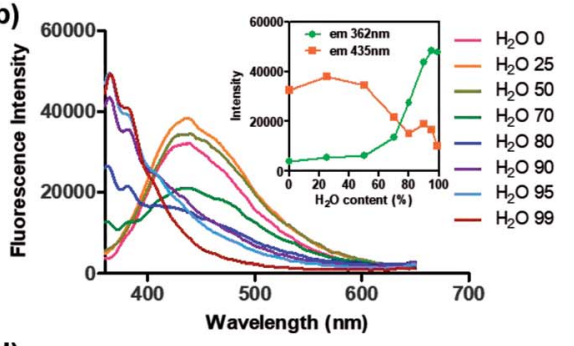

(d)

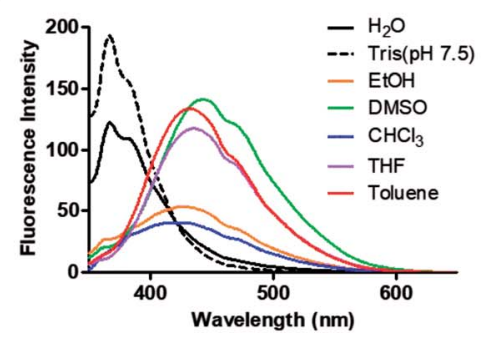

Fig. 4 (a) Photographs of $10 \mu \mathrm{M} 8 \mathrm{~g}(0-99 \%)$ under UV light $\left(\lambda_{\text {ex }}=312 \mathrm{~nm}\right)$. (b) Fluorescence spectra of $10 \mu \mathrm{M} 8 \mathrm{~g}$ in THF/water mixture $(0-99 \%)$ excited at $339 \mathrm{~nm}$; inset: plots of fluorescence intensity at $362 \mathrm{~nm}$ and $435 \mathrm{~nm}$. Absorption spectra of $8 \mathrm{~g}$ in $20 \mu \mathrm{M}$ (c) and emission spectra in $2 \mu \mathrm{M}$ (d) measured in various solvents. 
(a)

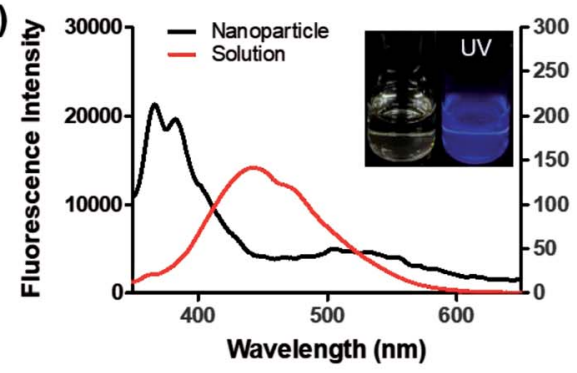

(b)

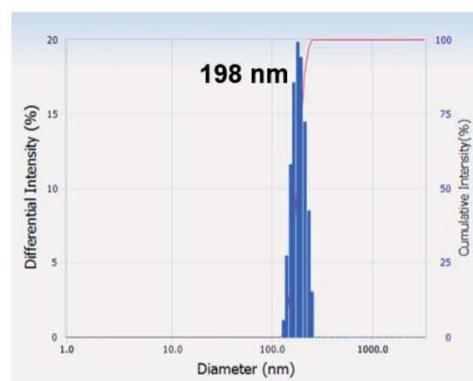

Fig. 5 (a) Emission spectra of $8 \mathrm{~g} 10 \mu \mathrm{M}$ nanoparticles (water : THF $=99: 1, \mathrm{v} / \mathrm{v}$ ) and $2 \mu \mathrm{M}$ in DMSO ( $\lambda_{\mathrm{ex}}=339 \mathrm{~nm}$ ); inset: photographs of $8 \mathrm{~g}$ nanoparticles under UV light $\left(\lambda_{\mathrm{ex}}=312 \mathrm{~nm}\right)$. (b) Particle size intensity distribution of $8 \mathrm{~g}$ nanoparticles.

fluorescence in solution along with good cell permeability, demonstrating potential for bioimaging applications.

\section{Experimental section}

\section{General methods}

Unless specified, all reagents and starting materials were purchased from commercial sources and used as received without purification. "Concentrated" refers to the removal of volatile solvents via distillation using a rotary evaporator. "Dried" refers to pouring onto, or passing through, anhydrous magnesium sulfate followed by filtration. Flash chromatography was performed using silica gel (230-400 mesh) with hexanes, ethyl acetate, and dichloromethane as the eluents. All reactions were monitored by thin-layer chromatography on $0.25 \mathrm{~mm}$ silica plates (F-254) visualized with UV light. Melting points were measured using a capillary melting point apparatus. ${ }^{1} \mathrm{H}$ and ${ }^{13} \mathrm{C}$ NMR spectra were recorded on a $400 \mathrm{MHz}$ NMR spectrometer and were described as chemical shifts, multiplicity (s, singlet; d, doublet; t, triplet; q, quartet; $\mathrm{m}$, multiplet), coupling constant in hertz $(\mathrm{Hz})$, and number of protons. HRMS were measured with an electrospray ionization (ESI) and Q-TOF mass analyzer.

\section{General procedure A for the synthesis of 8}

After a solution of $5(0.188 \mathrm{mmol})$ and $o$-phenylenediamine ( $0.244 \mathrm{mmol}, 1.3$ equiv.) in TFA ( $0.056 \mathrm{mmol}, 0.3$ equiv.)/DMSO (1 $\mathrm{mL}$ ) was stirred at room temperature for $8 \mathrm{~h}$, the reaction mixture

Table 4 Optical properties and quantum yield of $8 \mathrm{~h}, 8 \mathrm{k}, 8 \mathrm{z}, 8 \mathrm{ab}, 8 \mathrm{ae}$, $8 \mathrm{ah}, 9$, and 11

\begin{tabular}{|c|c|c|c|c|c|c|}
\hline \multirow[b]{2}{*}{ Compound } & \multirow[b]{2}{*}{$\lambda_{\mathrm{abs}}(\mathrm{nm})$} & \multicolumn{3}{|c|}{$\lambda_{\mathrm{em}}(\mathrm{nm})$} & \multirow[b]{2}{*}{$\varepsilon_{\max }\left(\mathrm{M}^{-1} \mathrm{~cm}^{-1}\right)$} & \multirow[b]{2}{*}{$\Phi_{\mathrm{f}}$} \\
\hline & & $\mathrm{H}_{2} \mathrm{O}$ & EtOH & DMSO & & \\
\hline $8 \mathrm{~h}$ & 360 & 414.0 & 412.5 & 422.0 & 19900 & 0.39 \\
\hline 8k & 361 & 413.5 & 412.5 & 421.5 & 18600 & 0.56 \\
\hline $8 z$ & 360 & 416.5 & 413.0 & 423.0 & 25500 & 0.43 \\
\hline $8 a b$ & 361 & 413.0 & 412.0 & 420.5 & 25900 & 0.42 \\
\hline $8 \mathbf{a e}$ & 360 & 415.5 & 416.0 & 425.5 & 16900 & 0.37 \\
\hline 8 ah & 361 & 416.0 & 415.5 & 425.5 & 19800 & 0.34 \\
\hline 9 & 334 & 355.0 & 353.0 & 356.5 & 29600 & 0.15 \\
\hline 11 & 348 & 421.5 & 414.0 & 419.0 & 17300 & 0.25 \\
\hline
\end{tabular}

was stirred at $65{ }^{\circ} \mathrm{C}$ for additional $3 \mathrm{~h}$. The reaction mixture was quenched with $\mathrm{H}_{2} \mathrm{O}(10 \mathrm{~mL})$ and extracted with ethyl acetate $(5 \mathrm{~mL} \times 3)$. The organic layer was dried over $\mathrm{MgSO}_{4}$ and concentrated under reduced pressure to give the crude residue, which was purified by silica gel column chromatography (hexane/ EtOAc/dichloromethane $=10: 1: 2$ ) to afford 8 .

\section{General procedure $B$ for the synthesis of 8}

After a solution of $5(0.188 \mathrm{mmol}), o$-phenylenediamine (0.244 mmol, 1.3 equiv.), and DBSA ( $0.0188 \mathrm{mmol}, 0.1$ equiv.) in toluene $(1 \mathrm{~mL})$ was stirred at $130{ }^{\circ} \mathrm{C}$ for $12 \mathrm{~h}$, the reaction mixture was concentrated in vacuo, diluted with $\mathrm{H}_{2} \mathrm{O}(10 \mathrm{~mL})$, and extracted with dichloromethane $(5 \mathrm{~mL} \times 3)$. The organic layer was dried over $\mathrm{MgSO}_{4}$ and concentrated under reduced pressure to give the crude residue, which was purified by silica gel column chromatography (hexane/EtOAc/dichloromethane $=10: 1: 2$ ) to afford 8. 6-Phenylbenzo $[4,5]$ imidazo $[1,2-a]$ pyrrolo $[2,1-c]$ pyrazine (8a).

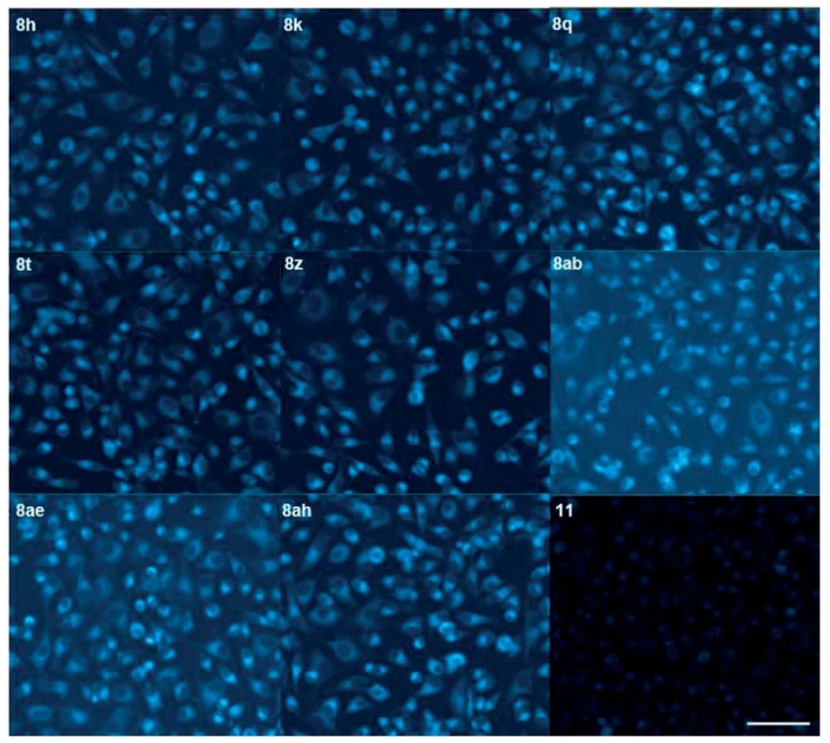

Fig. 6 Live-cell imaging and fluorescence of HeLa cells stained with $10 \mu \mathrm{M} 8 \mathrm{~h}, 8 \mathrm{k}, 8 \mathrm{q}, 8 \mathrm{t}, 8 \mathrm{z}, 8 \mathrm{ab}, 8 \mathrm{ae}, 8 \mathrm{ah}$ and 11 for $1 \mathrm{~h}$ from DAPI channel. Data were collected at $410-530 \mathrm{~nm}$ and images were obtained by Operetta high-content imaging system. Scale bar $=100 \mu \mathrm{m}$. 
Table 5 Photophysical properties of $8 \mathrm{a}, 8 \mathrm{c}, 8 \mathrm{~g}, 8 \mathrm{~h}$, and 11 in solid state

\begin{tabular}{llll}
\hline Compound & $\lambda_{\text {ex }}(\mathrm{nm})$ & $\lambda_{\text {em }}(\mathrm{nm})$ & $\tau_{\mathrm{f}}(\mathrm{ns})$ \\
\hline $\mathbf{8 a}$ & 349 & 369,495 & 7.11 \\
$\mathbf{8 c}$ & 353 & 370,481 & 5.53 \\
$\mathbf{8 g}$ & 353 & 396,496 & 8.31 \\
$\mathbf{8 h}$ & 382 & 521 & 4.32 \\
$\mathbf{1 1}$ & 377 & 492 & 8.95
\end{tabular}

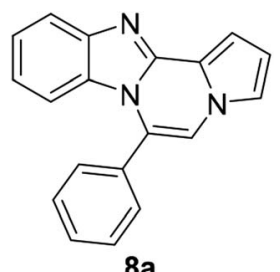

White solid, mp: $219.2-220.8{ }^{\circ} \mathrm{C}(44.7 \mathrm{mg}, 80 \%) ;{ }^{1} \mathrm{H}$ NMR $(400$ $\left.\mathrm{MHz}, \mathrm{CDCl}_{3}\right) \delta 7.84(\mathrm{~d}, J=8.0 \mathrm{~Hz}, 1 \mathrm{H}), 7.64-7.57(\mathrm{~m}, 5 \mathrm{H}), 7.34$ $(\mathrm{d}, J=2.8 \mathrm{~Hz}, 1 \mathrm{H}), 7.29(\mathrm{~d}, J=7.2 \mathrm{~Hz}, 1 \mathrm{H}), 7.26(\mathrm{~s}, 1 \mathrm{H}), 7.20$ $(\mathrm{s}, 1 \mathrm{H}), 6.93(\mathrm{t}, J=7.8 \mathrm{~Hz}, 1 \mathrm{H}), 6.74(\mathrm{t}, J=3.0 \mathrm{~Hz}, 1 \mathrm{H}), 6.33(\mathrm{~d}$, $J=8.4 \mathrm{~Hz}, 1 \mathrm{H}) ;{ }^{13} \mathrm{C}\left\{{ }^{1} \mathrm{H}\right\}$ NMR $\left(100 \mathrm{MHz}, \mathrm{CDCl}_{3}\right) \delta 144.5$, 143.1, 131.3, 130.5, 130.2, 130.1, 128.9, 124.4, 123.7, 121.4, 120.9, 119.4, 117.8, 113.2, 113.0, 111.7, 106.4; HRMS (ESIQTOF) $m / z[\mathrm{M}+\mathrm{H}]^{+}$calcd for $\mathrm{C}_{19} \mathrm{H}_{14} \mathrm{~N}_{3}$ 284.1182, found 284.1183.

2-(2-(1H-Benzo[d]imidazol-2-yl)-1H-pyrrol-1-yl)-1phenylethan-1-one (I).

(a)

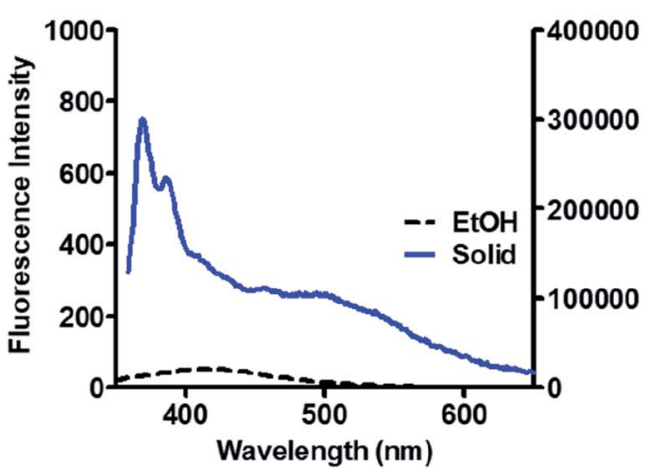

(c)

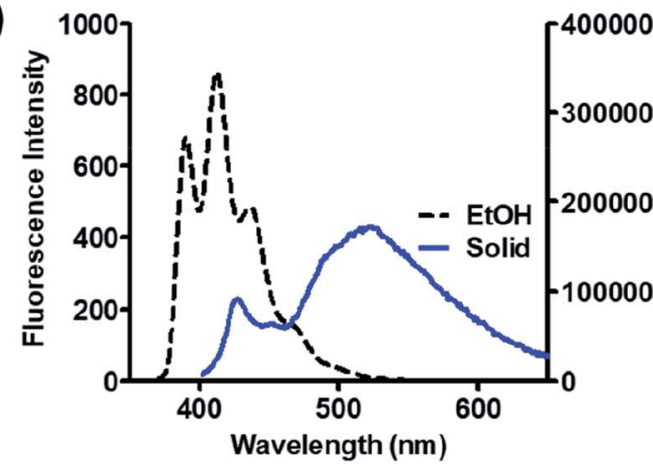<smiles>O=C(Cn1cccc1-c1nc2ccccc2[nH]1)c1ccccc1</smiles>

Pale yellow liquid (46.5 mg, 82\%); ${ }^{1} \mathrm{H}$ NMR $\left(400 \mathrm{MHz}, \mathrm{CDCl}_{3}\right.$ ) $\delta 8.29(\mathrm{~s}, 1 \mathrm{H}), 8.00(\mathrm{~d}, J=7.6 \mathrm{~Hz}, 2 \mathrm{H}), 7.60(\mathrm{t}, J=7.2 \mathrm{~Hz}, 1 \mathrm{H})$, $7.48(\mathrm{~d}, J=7.6 \mathrm{~Hz}, 2 \mathrm{H}), 6.92(\mathrm{~d}, J=7.6 \mathrm{~Hz}, 1 \mathrm{H}), 6.85-6.84(\mathrm{~m}$, $2 \mathrm{H}), 6.75(\mathrm{~d}, J=2.4 \mathrm{~Hz}, 1 \mathrm{H}), 6.66(\mathrm{t}, J=7.6 \mathrm{~Hz}, 1 \mathrm{H}), 6.54(\mathrm{~d}, J$ $=7.6 \mathrm{~Hz}, 1 \mathrm{H}), 6.34(\mathrm{t}, J=2.8 \mathrm{~Hz}, 1 \mathrm{H}), 5.97(\mathrm{~s}, 2 \mathrm{H}) ;{ }^{13} \mathrm{C}\left\{{ }^{1} \mathrm{H}\right\}$ NMR $\left(100 \mathrm{MHz}, \mathrm{CDCl}_{3}\right) \delta 193.6,149.6,141.3,138.4,134.8$, 133.8, 130.3, 129.6, 128.9, 128.0, 126.4, 120.2, 118.4, 117.3, 114.9, 109.6, 55.7; HRMS (ESI-QTOF) $m / z[\mathrm{M}+\mathrm{H}]^{+}$calcd for $\mathrm{C}_{19} \mathrm{H}_{16} \mathrm{~N}_{3} \mathrm{O} 320.1288$, found 302.1289 .

9,10-Difluoro-6-phenylbenzo[4,5]imidazo[1,2-a]pyrrolo[2,1c]pyrazine (8b).<smiles></smiles>

White solid, mp: $223-224{ }^{\circ} \mathrm{C}(39.6 \mathrm{mg}, 66 \%) ;{ }^{1} \mathrm{H}$ NMR $(400 \mathrm{MHz}$, $\left.\mathrm{CDCl}_{3}\right) \delta 7.68-7.52(\mathrm{~m}, 6 \mathrm{H}), 7.29(\mathrm{~d}, J=2.8 \mathrm{H}, 1 \mathrm{H}), 7.26(\mathrm{~s}, 1 \mathrm{H})$, $7.22(\mathrm{~s}, 1 \mathrm{H}), 6.75-6.73(\mathrm{~m}, 1 \mathrm{H}), 6.06(\mathrm{dd}, J=11,2,7.4 \mathrm{~Hz}, 1 \mathrm{H})$;

(b)
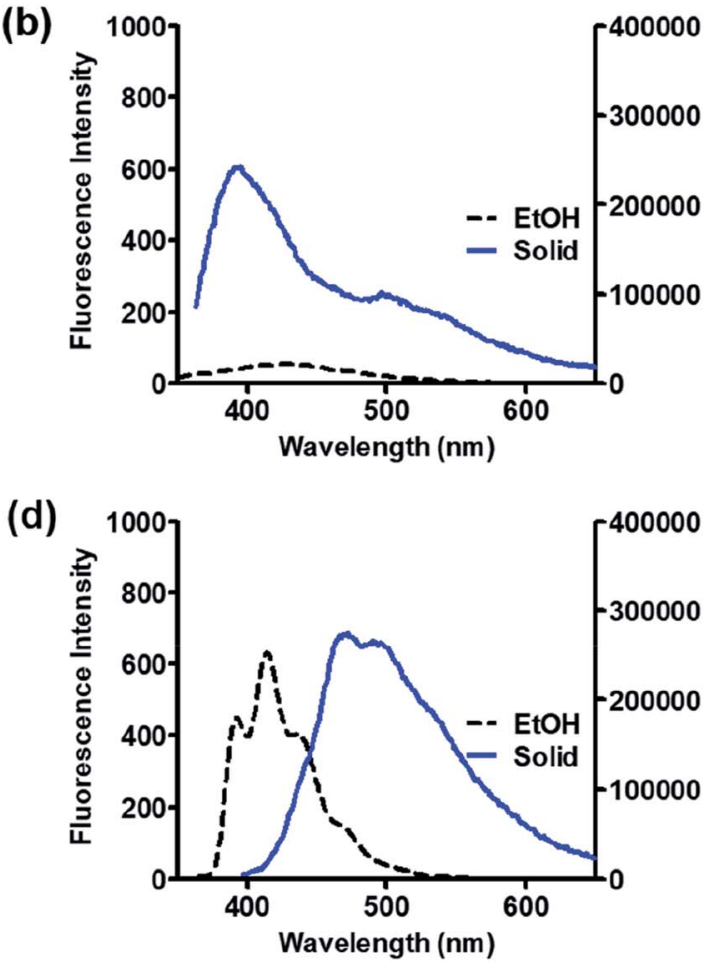

Fig. 7 Fluorescence spectra of $8 \mathrm{a}(\mathrm{a}), 8 \mathrm{~g}$ (b), 8h (c), and 11 (d) in EtOH (2 $\mu \mathrm{M}$, black) and solid states (blue). 
(a)

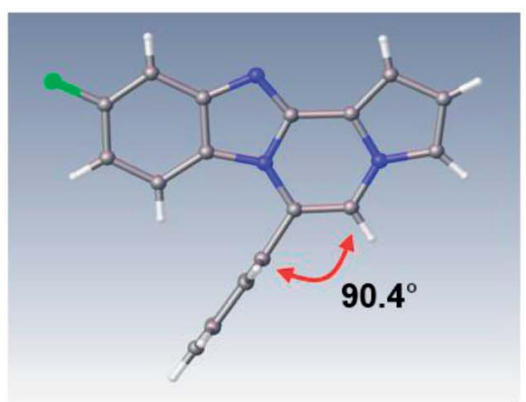

(c)

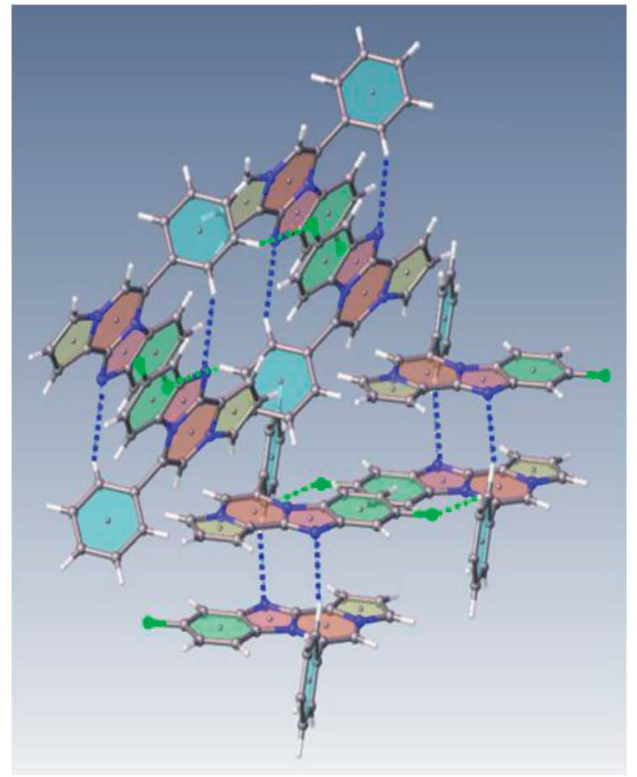

(b)

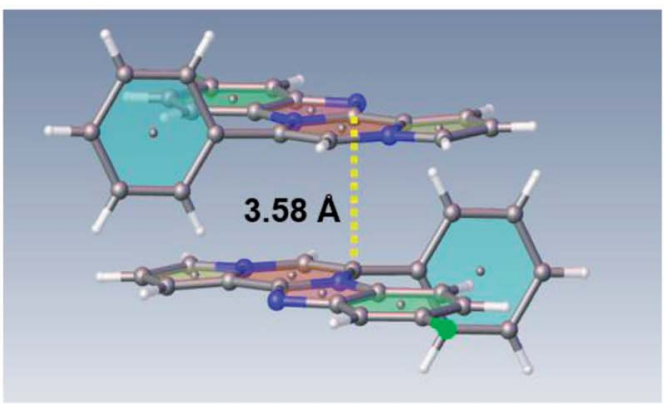

(d)

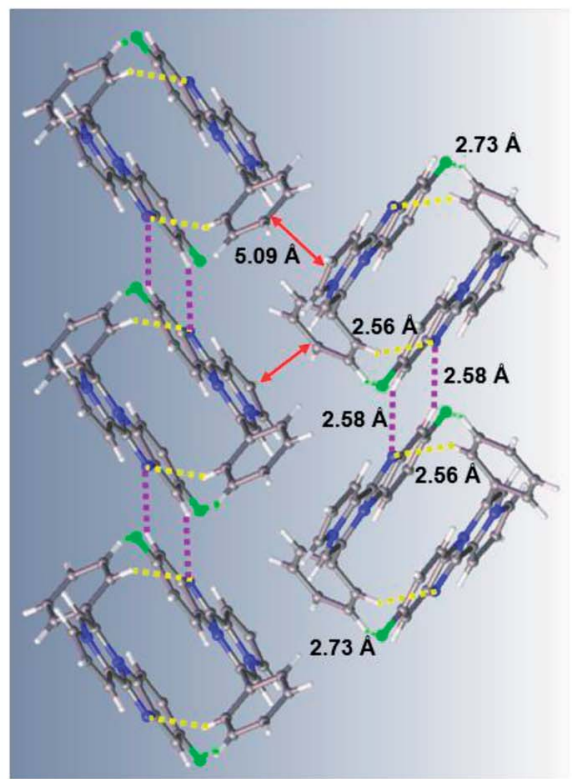

Fig. 8 (a) Crystal structure of $8 \mathrm{c}$ with a torsion angle of $90.4^{\circ}$. (b) Antiparallel $8 \mathrm{c}$ molecules aligned from a side view. (c) Antiparallel molecular packing diagram with intermolecular interactions. (d) Packing structure of $8 \mathrm{c}$ including intermolecular interactions; yellow: $\mathrm{CH} \cdots \mathrm{N}$ bond (2.56 $\AA$ ); purple: $\mathrm{CH} \cdots \mathrm{N}$ bond $(2.58 \AA)$; green: $\mathrm{CH} \cdots \mathrm{F}$ bond $(2.73 \AA$ Å).

${ }^{13} \mathrm{C}\left\{{ }^{1} \mathrm{H}\right\}$ NMR $\left(100 \mathrm{MHz}, \mathrm{CDCl}_{3}\right) \delta 149.6\left(\mathrm{~d}, J_{\mathrm{C}-\mathrm{F}}=14.5 \mathrm{~Hz}\right), 147.4$ $\left(\mathrm{dd}, J_{\mathrm{C}-\mathrm{F}}=37.9,14.8 \mathrm{~Hz}\right), 145.1\left(\mathrm{~d}, J_{\mathrm{C}-\mathrm{F}}=14.9 \mathrm{~Hz}\right), 144.4,140.1$ $\left(\mathrm{d}, J_{\mathrm{C}-\mathrm{F}}=7.9 \mathrm{~Hz}\right), 130.6,130.2,129.2,123.3,118.1,117.3,113.4$, 112.1, 107.5, 106.6, $106.3\left(\mathrm{~d}, J_{\mathrm{C}-\mathrm{F}}=19.8 \mathrm{~Hz}\right), 101.2\left(\mathrm{~d}, J_{\mathrm{C}-\mathrm{F}}=24.7\right.$ $\mathrm{Hz}$ ); HRMS (ESI-QTOF) $m / z[\mathrm{M}+\mathrm{Na}]^{+}$calcd for $\mathrm{C}_{19} \mathrm{H}_{11} \mathrm{~F}_{2} \mathrm{~N}_{3} \mathrm{Na}$ 342.0813 , found 342.0812 .

10-Fluoro-6-phenylbenzo[4,5]imidazo[1,2-a]pyrrolo[2,1-c] pyrazine (8c).<smiles>Fc1ccc2c(c1)nc1c3cccn3cc(-c3ccccc3)n21</smiles>

Pale yellow solid, mp: 193.7-194.5 ${ }^{\circ} \mathrm{C}$ (34.6 mg, 61\%); ${ }^{1} \mathrm{H}$ NMR $\left(400 \mathrm{MHz}, \mathrm{CDCl}_{3}\right) \delta 7.64-7.57(\mathrm{~m}, 5 \mathrm{H}), 7.47(\mathrm{dd}, J=9.2,2.4 \mathrm{~Hz}$, $1 \mathrm{H}), 7.33(\mathrm{~d}, J=3.6 \mathrm{~Hz}, 1 \mathrm{H}), 7.28(\mathrm{t}, J=1.2 \mathrm{~Hz}, 1 \mathrm{H}), 7.23(\mathrm{~s}, 1 \mathrm{H})$, 6.76-6.74 (m, 1H), $6.67(\mathrm{td}, J=9.2,1.2 \mathrm{~Hz}, 1 \mathrm{H}), 6.24-6.20(\mathrm{~m}, 1 \mathrm{H})$; ${ }^{13} \mathrm{C}\left\{{ }^{1} \mathrm{H}\right\} \mathrm{NMR}\left(100 \mathrm{MHz}, \mathrm{CDCl}_{3}\right) \delta 159.4\left(\mathrm{~d}, J_{\mathrm{C}-\mathrm{F}}=238.5 \mathrm{~Hz}\right), 145.4$ $\left(\mathrm{d}, J_{\mathrm{C}-\mathrm{F}}=12.9 \mathrm{~Hz}\right), 144.3,131.0,130.3\left(\mathrm{~d}, J_{\mathrm{C}-\mathrm{F}}=5.4 \mathrm{~Hz}\right), 129.0$,
127.1, 124.1, 120.7, 117.9, $113.3\left(\mathrm{~d}, J_{\mathrm{C}-\mathrm{F}}=4.0 \mathrm{~Hz}\right), 113.2,111.8$, 109.6, 109.4, 106.6, 105.0 (d, $J_{\mathrm{C}-\mathrm{F}}=24.0 \mathrm{~Hz}$ ); HRMS (ESI-QTOF) $m / z[\mathrm{M}+\mathrm{Na}]^{+}$calcd for $\mathrm{C}_{19} \mathrm{H}_{12} \mathrm{FN}_{3} \mathrm{Na} 324.0907$, found 324.0912.

9,10-Dichloro-6-phenylbenzo[4,5]imidazo[1,2-a]pyrrolo $[2,1$ c]pyrazine (8d).<smiles>Clc1cc2nc3c4cccn4cc(-c4ccccc4)n3c2cc1Cl</smiles>

Yellow solid, mp: $256.2-257.1{ }^{\circ} \mathrm{C}(50.2 \mathrm{mg}, 76 \%) ;{ }^{1} \mathrm{H}$ NMR (400 $\left.\mathrm{MHz}, \mathrm{CDCl}_{3}\right) \delta 7.87(\mathrm{~s}, 1 \mathrm{H}), 7.68(\mathrm{~d}, J=7.1 \mathrm{~Hz}, 1 \mathrm{H}), 7.62(\mathrm{t}, J=$ $7.4 \mathrm{~Hz}, 2 \mathrm{H}), 7.57$ (d, $J=7.2 \mathrm{~Hz}, 2 \mathrm{H}), 7.35$ (d, $J=3.6 \mathrm{~Hz}, 1 \mathrm{H}), 7.30$ (s, 1H), $7.27(\mathrm{~s}, 1 \mathrm{H}), 6.75(\mathrm{t}, J=7.0 \mathrm{~Hz}, 1 \mathrm{H}), 6.35(\mathrm{~s}, 1 \mathrm{H}) ;{ }^{13} \mathrm{C}\left\{{ }^{1} \mathrm{H}\right\} \mathrm{NMR}$ $\left(100 \mathrm{MHz}, \mathrm{CDCl}_{3}\right) \delta$ 144.6, 143.9, 130.6, 130.4, 130.1, 129.5, 129.2, 127.8, 125.0, 123.9, 120.3, 120.0, 118.5, 114.2, 113.6, 112.2, 107.4; HRMS (ESI-QTOF) $m / z[\mathrm{M}+\mathrm{H}]^{+}$calcd for $\mathrm{C}_{19} \mathrm{H}_{12} \mathrm{Cl}_{2} \mathrm{~N}_{3}$ 352.0403, found 352.0406 . 
10-Chloro-6-phenylbenzo[ $[4,5]$ imidazo $[1,2-a]$ pyrrolo $[2,1-c]$ pyrazine (8e).

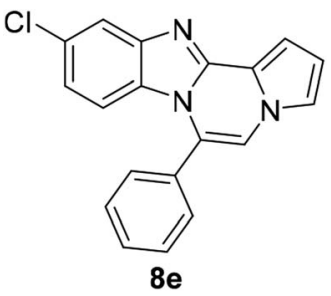

White solid, mp: $169.3-170.1{ }^{\circ} \mathrm{C}(35.1 \mathrm{mg}, 56 \%) ;{ }^{1} \mathrm{H}$ NMR (400 $\left.\mathrm{MHz}, \mathrm{CDCl}_{3}\right) \delta 7.78(\mathrm{~d}, J=1.6 \mathrm{~Hz}, 1 \mathrm{H}), 7.64-7.55(\mathrm{~m}, 5 \mathrm{H}), 7.34$ $(\mathrm{d}, J=3.6 \mathrm{~Hz}, 1 \mathrm{H}), 7.28(\mathrm{~d}, J=1.2 \mathrm{~Hz}, 1 \mathrm{H}), 7.24(\mathrm{~s}, 1 \mathrm{H}), 6.89$ (dd, $J=9.0,1.8 \mathrm{~Hz}, 1 \mathrm{H}), 6.76(\mathrm{t}, J=3.2 \mathrm{~Hz}, 1 \mathrm{H}), 6.21(\mathrm{~d}, J=9.2 \mathrm{~Hz}$, $1 \mathrm{H}) ;{ }^{13} \mathrm{C}\left\{{ }^{1} \mathrm{H}\right\} \mathrm{NMR}\left(100 \mathrm{MHz}, \mathrm{CDCl}_{3}\right) \delta 145.5,144.1,131.0,130.3$, 130.2, 129.3, 129.1, 129.05, 124.1, 121.7, 120.6, 119.0, 118.1, 113.5, 113.4, 112.0, 106.9; HRMS (ESI-QTOF) $m / z[\mathrm{M}+\mathrm{H}]^{+}$calcd for $\mathrm{C}_{19} \mathrm{H}_{13} \mathrm{ClN}_{3}$ 318.0793, found 318.0791.

9,10-Dibromo-6-phenylbenzo[4,5]imidazo[1,2-a]pyrrolo[2,1c]pyrazine (8f).<smiles>Brc1cc2nc3c4cccn4cc(-c4ccccc4)n3c2cc1Br</smiles>

White solid, mp: $289.3-290.2{ }^{\circ} \mathrm{C}(51.5 \mathrm{mg}, 62 \%) ;{ }^{1} \mathrm{H}$ NMR (400 $\left.\mathrm{MHz} \mathrm{CDCl}_{3}\right) \delta 8.06(\mathrm{~s}, 1 \mathrm{H}), 7.68(\mathrm{t}, J=7.4 \mathrm{~Hz}, 1 \mathrm{H}), 7.62(\mathrm{t}, J=$ $7.4 \mathrm{~Hz}, 2 \mathrm{H}), 7.56(\mathrm{~d}, J=7.2 \mathrm{~Hz}, 2 \mathrm{H}), 7.35$ (d, $J=4.0 \mathrm{~Hz}, 1 \mathrm{H}), 7.31-$ $7.30(\mathrm{~m}, 1 \mathrm{H}), 7.26(\mathrm{~s}, 1 \mathrm{H}), 6.78-6.77(\mathrm{~m}, 1 \mathrm{H}), 6.52(\mathrm{~s}, 1 \mathrm{H}) ;{ }^{13} \mathrm{C}\left\{{ }^{1} \mathrm{H}\right\}$ NMR $\left(100 \mathrm{MHz}, \mathrm{CDCl}_{3}\right) \delta 144.8,144.4,130.6,130.2,129.2,123.9$, 123.3, 123.29, 120.2, 119.1, 118.6, 117.3, 117.3, 116.2, 113.6, 112.3, 107.5; HRMS (ESI-QTOF) $m / z[\mathrm{M}+\mathrm{H}]^{+}$calcd for $\mathrm{C}_{19} \mathrm{H}_{12} \mathrm{Br}_{2} \mathrm{~N}_{3}$ 439.9392, found 439.9391 .

9,10-Dimethyl-6-phenylbenzo[4,5]imidazo[1,2-a]pyrrolo[2,1c]pyrazine (8g).<smiles>Cc1cc2nc3c4cccn4cc(-c4ccccc4)n3c2cc1C</smiles>

White solid, mp: $230-231.8{ }^{\circ} \mathrm{C}(47.0 \mathrm{mg}, 80 \%) ;{ }^{1} \mathrm{H}$ NMR $(400 \mathrm{MHz}$, $\left.\mathrm{CDCl}_{3}\right) \delta 7.64-7.56(\mathrm{~m}, 6 \mathrm{H}), 7.29(\mathrm{~d}, J=3.6 \mathrm{~Hz}, 1 \mathrm{H}), 7.22(\mathrm{~d}, J=$ $1.2 \mathrm{~Hz}, 1 \mathrm{H}), 7.16(\mathrm{~s}, 1 \mathrm{H}), 6.72(\mathrm{t}, J=3.0 \mathrm{~Hz}, 1 \mathrm{H}), 6.07(\mathrm{~s}, 1 \mathrm{H}), 2.33$ $(\mathrm{s}, 3 \mathrm{H}), 2.10(\mathrm{~s}, 3 \mathrm{H}) ;{ }^{13} \mathrm{C}\left\{{ }^{1} \mathrm{H}\right\} \mathrm{NMR}\left(100 \mathrm{MHz}, \mathrm{CDCl}_{3}\right) \delta 143.1,142.5$, 132.6, 131.5, 130.3, 130.26, 130.0, 128.9, 128.8, 124.4, 121.2, 119.4, 117.4, 113.3, 112.9, 111.3, 105.7, 20.6, 20.2; HRMS (ESI-QTOF) $\mathrm{m} / \mathrm{z}$ $[\mathrm{M}+\mathrm{Na}]^{+}$calcd for $\mathrm{C}_{21} \mathrm{H}_{17} \mathrm{~N}_{3} \mathrm{Na} 334.1315$, found 334.1314.

6-Phenylnaphtho $\left[2^{\prime}, 3^{\prime}: 4,5\right]$ imidazo $[1,2-a]$ pyrrolo $[2,1-c]$ pyrazine (8h).

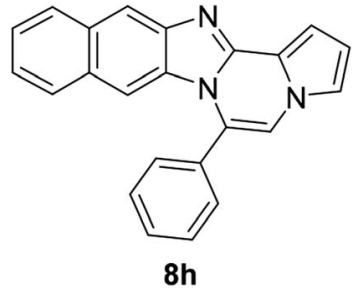

White solid, mp: $232-233{ }^{\circ} \mathrm{C}(49.6 \mathrm{mg}, 79 \%) ;{ }^{1} \mathrm{H}$ NMR $(400 \mathrm{MHz}$, $\left.\mathrm{CDCl}_{3}\right) \delta 8.25(\mathrm{~s}, 1 \mathrm{H}), 7.95(\mathrm{~d}, J=8.4 \mathrm{~Hz}, 1 \mathrm{H}), 7.72-7.60(\mathrm{~m}, 5 \mathrm{H})$, $7.50(\mathrm{~d}, J=8.0 \mathrm{~Hz}, 1 \mathrm{H}), 7.44(\mathrm{~d}, J=3.2 \mathrm{~Hz}, 1 \mathrm{H}), 7.38(\mathrm{t}, J=$ $7.4 \mathrm{~Hz}, 1 \mathrm{H}), 7.29(\mathrm{t}, J=7.2 \mathrm{~Hz}, 2 \mathrm{H}), 7.20(\mathrm{~s}, 1 \mathrm{H}), 6.77(\mathrm{t}, J=$ $3.2 \mathrm{~Hz}, 1 \mathrm{H}), 6.70(\mathrm{~s}, 1 \mathrm{H}) ;{ }^{13} \mathrm{C}\left\{{ }^{1} \mathrm{H}\right\} \mathrm{NMR}\left(100 \mathrm{MHz}, \mathrm{CDCl}_{3}\right) \delta 146.0$, 144.4 , 131.3, 131.2, 130.8, 130.3, 130.2, 129.2, 129.0, 128.0, $127.8,124.8,124.2,123.8,120.5,118.7,115.4,113.4,111.0$, 109.8, 108.0; HRMS (ESI-QTOF) $\mathrm{m} / z[\mathrm{M}+\mathrm{Na}]^{+}$calcd for $\mathrm{C}_{23} \mathrm{H}_{15} \mathrm{~N}_{3} \mathrm{Na} 356.1158$, found 356.1154.

6-(4-Fluorophenyl)benzo[4,5]imidazo[1,2-a]pyrrolo[2,1-c]pyrazine (8i).

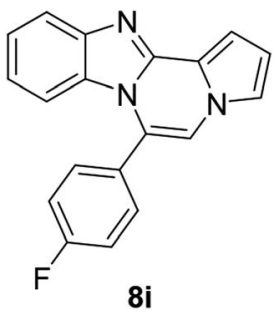

Brown solid, mp: $168-170{ }^{\circ} \mathrm{C}(36.9 \mathrm{mg}, 65 \%) ;{ }^{1} \mathrm{H}$ NMR $(400 \mathrm{MHz}$, $\left.\mathrm{CDCl}_{3}\right) \delta 7.98(\mathrm{~d}, J=8.0 \mathrm{~Hz}, 1 \mathrm{H}), 7.63(\mathrm{~d}, J=4.8 \mathrm{~Hz}, 2 \mathrm{H}), 7.60(\mathrm{~s}, 1 \mathrm{H})$, $7.46(\mathrm{~s}, 1 \mathrm{H}), 7.42-7.37(\mathrm{~m}, 2 \mathrm{H}), 7.33(\mathrm{t}, J=7.8 \mathrm{~Hz}, 2 \mathrm{H}), 7.08(\mathrm{t}, J=$ $7.8 \mathrm{~Hz}, 1 \mathrm{H}), 6.76(\mathrm{~s}, 1 \mathrm{H}), 6.36(\mathrm{~d}, J=8.4 \mathrm{~Hz}, 1 \mathrm{H}) ;{ }^{13} \mathrm{C}\left\{{ }^{1} \mathrm{H}\right\} \mathrm{NMR}(100$ $\left.\mathrm{MHz} \mathrm{CDCl}_{3}\right) \delta 165.6\left(\mathrm{~d}, J_{\mathrm{C}-\mathrm{F}}=251.1 \mathrm{~Hz}\right), 147.3,140.1,132.5\left(\mathrm{~d}, J_{\mathrm{C}-\mathrm{F}}\right.$ $=8.5 \mathrm{~Hz}), 128.8,126.0,125.9,123.5,122.6,120.0,118.1,117.2,116.6$ $\left(\mathrm{d}, J_{\mathrm{C}-\mathrm{F}}=21.8 \mathrm{~Hz}\right), 115.1,114.1,113.4,110.2$; HRMS (ESI-QTOF) $\mathrm{m} / \mathrm{z}$ $[\mathrm{M}+\mathrm{H}]^{+}$calcd for $\mathrm{C}_{19} \mathrm{H}_{13} \mathrm{FN}_{3}$ 302.1088, found 302.1085.

9,10-Dichloro-6-(4-fluorophenyl)benzo[4,5]imidazo[1,2-a] pyrrolo[2,1-c]pyrazine $(8 \mathrm{j})$.<smiles>Fc1ccc(-c2cn3cccc3c3nc4cc(Cl)c(Cl)cc4n23)cc1</smiles>

White solid, mp: 301.4-302.5 ${ }^{\circ} \mathrm{C}(31.3 \mathrm{mg}, 45 \%) ;{ }^{1} \mathrm{H}$ NMR (400 MHz, $\left.\mathrm{CDCl}_{3}\right) \delta 7.88(\mathrm{~s}, 1 \mathrm{H}), 7.58-7.55(\mathrm{~m}, 2 \mathrm{H}), 7.35-7.30(\mathrm{~m}, 4 \mathrm{H}), 7.24(\mathrm{~s}$, $1 \mathrm{H}), 6.78(\mathrm{t}, J=3.2 \mathrm{~Hz}, 1 \mathrm{H}), 6.40(\mathrm{~s}, 1 \mathrm{H}) ;{ }^{13} \mathrm{C}\left\{{ }^{1} \mathrm{H}\right\} \mathrm{NMR}(100 \mathrm{MHz}$, $\left.\mathrm{CDCl}_{3}\right) \delta 163.9\left(\mathrm{~d}, J_{\mathrm{C}-\mathrm{F}}=250.6 \mathrm{~Hz}\right), 144.5,143.9,132.2\left(\mathrm{~d}, J_{\mathrm{C}-\mathrm{F}}=8.3\right.$ $\mathrm{Hz}), 129.4,127.9,125.1,122.8,120.2,118.6,116.5$ (d, $\left.J_{\mathrm{C}-\mathrm{F}}=21.7 \mathrm{~Hz}\right)$, 116.3, 115.8, 113.8 (d, $\left.J_{\mathrm{C}-\mathrm{F}}=2.9 \mathrm{~Hz}\right), 112.6,107.5$, 107.3; HRMS (ESIQTOF) $m / z[\mathrm{M}+\mathrm{H}]^{+}$calcd for $\mathrm{C}_{19} \mathrm{H}_{11} \mathrm{Cl}_{2} \mathrm{FN}_{3} 370.0309$, found 370.0311 .

6-(4-Fluorophenyl)naphtho[ $\left[2^{\prime}, 3^{\prime}: 4,5\right]$ imidazo $[1,2-a]$ pyrrolo $[2,1-c]$ pyrazine (8k). 
<smiles>Fc1ccc(-c2cn3cccc3c3nc4cc5ccccc5cc4n23)cc1</smiles>

Pale brown solid, mp: 241.5-242.2 ${ }^{\circ} \mathrm{C}$ (57.4 mg, 87\%); ${ }^{1} \mathrm{H}$ NMR $\left(400 \mathrm{MHz} \mathrm{CDCl}_{3}\right) \delta 8.25(\mathrm{~s}, 1 \mathrm{H}), 7.50(\mathrm{~d}, J=8.4 \mathrm{~Hz}, 1 \mathrm{H}), 7.63(\mathrm{t}, J=$ $6.8 \mathrm{~Hz}, 2 \mathrm{H}), 7.53(\mathrm{~d}, J=8.4 \mathrm{~Hz}, 1 \mathrm{H}), 7.43(\mathrm{~d}, J=3.2 \mathrm{~Hz}, 1 \mathrm{H}), 7.39(\mathrm{t}$, $J=7.4 \mathrm{~Hz}, 1 \mathrm{H}), 7.35-7.28(\mathrm{~m}, 4 \mathrm{H}), 7.17(\mathrm{~s}, 1 \mathrm{H}), 6.76(\mathrm{t}, J=2.8 \mathrm{~Hz}$, $1 \mathrm{H}), 6.72(\mathrm{~s}, 1 \mathrm{H}) ;{ }^{13} \mathrm{C}\left\{{ }^{1} \mathrm{H}\right\} \mathrm{NMR}\left(100 \mathrm{MHz}, \mathrm{CDCl}_{3}\right) \delta 163.8\left(\mathrm{~d}, J_{\mathrm{C}-\mathrm{F}}=\right.$ $249.5 \mathrm{~Hz}$ ), 145.9, 144.3, 132.3 (d, $\left.J_{\mathrm{C}-\mathrm{F}}=8.4 \mathrm{~Hz}\right), 131.1,130.9,129.2$, $127.9,127.8,127.4,124.3,124.0,123.7,120.5,118.8,116.1$ (d, $J_{\mathrm{C}-\mathrm{F}}$ $=21.7 \mathrm{~Hz}), 115.6,113.5,111.3,109.5,108.1$; HRMS (ESI-QTOF) $\mathrm{m} / \mathrm{z}$ $[\mathrm{M}+\mathrm{H}]^{+}$calcd for $\mathrm{C}_{23} \mathrm{H}_{15} \mathrm{FN}_{3} 352.1245$, found 352.1240.

6-(4-Chlorophenyl)benzo[4,5]imidazo[1,2-a]pyrrolo[2,1-c] pyrazine $(8 \mathrm{~m})$.<smiles>Clc1ccc(-c2cn3cccc3c3nc4ccccc4n23)cc1</smiles>

White solid, mp: $208-209.6{ }^{\circ} \mathrm{C}(51.1 \mathrm{mg}, 86 \%) ;{ }^{1} \mathrm{H}$ NMR $(400 \mathrm{MHz}$, $\left.\mathrm{CDCl}_{3}\right) \delta 7.85(\mathrm{~d}, J=8.0 \mathrm{~Hz}, 1 \mathrm{H}), 7.58-7.52(\mathrm{~m}, 4 \mathrm{H}), 7.35-7.28(\mathrm{~m}$, $3 \mathrm{H}), 7.20(\mathrm{~s}, 1 \mathrm{H}), 7.00(\mathrm{t}, J=8.0 \mathrm{~Hz}, 1 \mathrm{H}), 6.76(\mathrm{t}, J=6.8 \mathrm{~Hz}, 1 \mathrm{H}), 6.42$ $(\mathrm{d}, J=8.4 \mathrm{~Hz}, 1 \mathrm{H}) ;{ }^{13} \mathrm{C}\left\{{ }^{1} \mathrm{H}\right\} \mathrm{NMR}\left(100 \mathrm{MHz}, \mathrm{CDCl}_{3}\right) \delta$ 144.5, 143.0, 136.3, 131.5, 130.3, 129.8, 129.3, 123.9, 123.2, 121.6, 120.9, 119.5, 117.9, 113.4, 112.8, 112.0, 106.6; HRMS (ESI-QTOF) $m / z[\mathrm{M}+\mathrm{H}]^{+}$ calcd for $\mathrm{C}_{19} \mathrm{H}_{13} \mathrm{ClN}_{3}$ 318.0793, found 318.0798.

6-(4-Chlorophenyl)-9,10-difluorobenzo[4,5]imidazo[1,2-a] pyrrolo[2,1-c]pyrazine (8n).

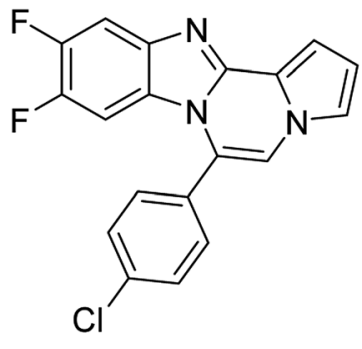

$8 n$

White solid, mp: $232.7-233.4{ }^{\circ} \mathrm{C}(46.3 \mathrm{mg}, 70 \%) ;{ }^{1} \mathrm{H}$ NMR $(400$ $\left.\mathrm{MHz}, \mathrm{CDCl}_{3}\right) \delta 7.60-7.51(\mathrm{~m}, 5 \mathrm{H}), 7.30(\mathrm{~m}, 2 \mathrm{H}), 7.21(\mathrm{~s}, 1 \mathrm{H}), 6.76(\mathrm{~s}$, $1 \mathrm{H}), 6.20(\mathrm{t}, J=8.4 \mathrm{~Hz}, 1 \mathrm{H}) ;{ }^{13} \mathrm{C}\left\{{ }^{1} \mathrm{H}\right\} \mathrm{NMR}\left(100 \mathrm{MHz}, \mathrm{CDCl}_{3}\right) \delta 149.6$ $\left(\mathrm{d}, J_{\mathrm{C}-\mathrm{F}}=14.1 \mathrm{~Hz}\right), 147.4\left(\mathrm{dd}, J_{\mathrm{C}-\mathrm{F}}=14.7,14.4 \mathrm{~Hz}\right), 145.2\left(\mathrm{~d}, J_{\mathrm{C}-\mathrm{F}}=\right.$ $14.9 \mathrm{~Hz}), 144.3\left(\mathrm{~d}, J_{\mathrm{C}-\mathrm{F}}=2.7 \mathrm{~Hz}\right), 140.1\left(\mathrm{~d}, J_{\mathrm{C}-\mathrm{F}}=10.4 \mathrm{~Hz}\right), 136.8$, 131.4, 129.5, 128.9, 122.6, 120.5, 118.2 113.6, 112.4, 106.8, 106.4 (d,
$\left.J_{\mathrm{C}-\mathrm{F}}=19.3 \mathrm{~Hz}\right), 101.0\left(\mathrm{~d}, J_{\mathrm{C}-\mathrm{F}}=24.5 \mathrm{~Hz}\right.$ ); HRMS (ESI-QTOF) $\mathrm{m} / z$ [M $+\mathrm{H}]^{+}$calcd for $\mathrm{C}_{19} \mathrm{H}_{11} \mathrm{ClF}_{2} \mathrm{~N}_{3} 354.0604$, found 345.0608.

9,10-Dichloro-6-(4-chlorophenyl)benzo[4,5]imidazo[1,2-a] pyrrolo[2,1-c]pyrazine (80).<smiles>O=S(=O)(O)c1ccc(-c2cn3cccc3c3nc4cc(Cl)c(Cl)cc4n23)cc1</smiles>

White solid, mp: $294.2-294.4{ }^{\circ} \mathrm{C}(58.8 \mathrm{mg}, 81 \%) ;{ }^{1} \mathrm{H}$ NMR (400 $\left.\mathrm{MHz} \mathrm{CDCl}_{3}\right) \delta 7.89(\mathrm{~s}, 1 \mathrm{H}), 7.61(\mathrm{~d}, J=8.4 \mathrm{~Hz}, 2 \mathrm{H}), 7.52$ (d, $J=$ $8.4 \mathrm{~Hz}, 2 \mathrm{H}), 7.34(\mathrm{~d}, J=3.2 \mathrm{~Hz}, 1 \mathrm{H}), 7.30(\mathrm{~s}, 1 \mathrm{H}), 7.22(\mathrm{~s}, 1 \mathrm{H}), 6.78$ $(\mathrm{t}, J=3.4 \mathrm{~Hz}, 1 \mathrm{H}), 6.50(\mathrm{~s}, 1 \mathrm{H}) ;{ }^{13} \mathrm{C}\left\{{ }^{1} \mathrm{H}\right\} \mathrm{NMR}\left(100 \mathrm{MHz}, \mathrm{CDCl}_{3}\right)$ $\delta 144.5,143.9,136.9,131.4,129.5,129.3,128.9,128.0,125.2$, 122.7, 120.2, 118.6, 113.9, 113.8, 112.6, 107.6; HRMS (ESI-QTOF) $m / z[\mathrm{M}+\mathrm{H}]^{+}$calcd for $\mathrm{C}_{19} \mathrm{H}_{11} \mathrm{Cl}_{3} \mathrm{~N}_{3} 386.0013$, found 386.0019.

6-(4-Chlorophenyl)-9,10-dimethylbenzo[4,5]imidazo[1,2-a] pyrrolo[2,1-c]pyrazine $(8 p)$.<smiles>Cc1cc2nc3c4cccn4cc(-c4ccc(Cl)cc4)n3c2cc1C</smiles>

Pale yellow solid, mp: $256.8-257.0{ }^{\circ} \mathrm{C}(40.8 \mathrm{mg}, 63 \%) ;{ }^{1} \mathrm{H}$ NMR (400 $\left.\mathrm{MHz}, \mathrm{CDCl}_{3}\right) \delta 7.60-7.51(\mathrm{~m}, 5 \mathrm{H}), 7.28(\mathrm{~d}, J=3.2 \mathrm{~Hz}, 1 \mathrm{H}), 7.23(\mathrm{~s}$, 1H), 7.15 (s, 1H), $6.73(\mathrm{t}, J=3.0 \mathrm{~Hz}, 1 \mathrm{H}), 6.18(\mathrm{~s}, 1 \mathrm{H}), 2.34(\mathrm{~s}, 3 \mathrm{H})$, $2.15(\mathrm{~s}, 3 \mathrm{H}) ;{ }^{13} \mathrm{C}\left\{{ }^{1} \mathrm{H}\right\} \mathrm{NMR}\left(100 \mathrm{MHz}, \mathrm{CDCl}_{3}\right) \delta 143.1,142.4,136.2$, 132.8, 131.5, 130.6, 130.0, 129.1, 128.7, 123.2, 121.1, 119.6, 117.5, 113.2, 113.0, 111.6, 106.0, 20.7, 20.6; HRMS (ESI-QTOF) $\mathrm{m} / \mathrm{z}[\mathrm{M}+$ $\mathrm{H}]^{+}$calcd for $\mathrm{C}_{21} \mathrm{H}_{17} \mathrm{ClN}_{3} 346.1106$, found 346.1110.

6-(4-Chlorophenyl)naphtho $\left[2^{\prime}, 3^{\prime}: 4,5\right]$ imidazo $[1,2-a]$ pyrrolo $[2,1-c]$ pyrazine $(8 q)$.<smiles>O=C(c1ccc(Cl)cc1)c1cn2cccc2c2nc3cc4ccccc4cc3n12</smiles>

Pale brown solid, mp: 278.2-278.4 ${ }^{\circ} \mathrm{C}$ (49.9 mg, $\left.72 \%\right) ;{ }^{1} \mathrm{H}$ NMR (400 MHz, $\left.\mathrm{CDCl}_{3}\right) \delta 8.29(\mathrm{~s}, 1 \mathrm{H}), 7.96(\mathrm{~d}, J=8.0 \mathrm{~Hz}, 1 \mathrm{H})$, $7.64-7.57(\mathrm{~m}, 5 \mathrm{H}), 7.51(\mathrm{~s}, 1 \mathrm{H}), 7.41(\mathrm{t}, J=7.2 \mathrm{~Hz}, 1 \mathrm{H}), 7.33(\mathrm{~s}$, 2H), $7.23(\mathrm{~s}, 1 \mathrm{H}), 6.80(\mathrm{~s}, 2 \mathrm{H}) ;{ }^{13} \mathrm{C}\left\{{ }^{1} \mathrm{H}\right\}$ NMR (100 MHz, $\left.\mathrm{CDCl}_{3}\right)$ 
$\delta$ 136.7, 131.6, 131.0, 130.5, 129.4, 129.3, 128.3, 128.0, 127.8, $124.8,124.7,124.3,123.5,119.3,118.3,117.3,115.2,114.0$, 111.9, 109.8, 109.1; HRMS (ESI-QTOF) $m / z[\mathrm{M}+\mathrm{H}]^{+}$calcd for $\mathrm{C}_{23} \mathrm{H}_{15} \mathrm{ClN}_{3} 368.0949$, found 368.0950.

6-(4-Bromophenyl)benzo[4,5]imidazo[1,2-a]pyrrolo[2,1-c] pyrazine (8r).

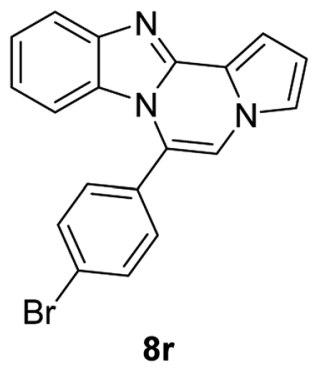

White solid, mp: $197.7-198.4{ }^{\circ} \mathrm{C}(46 \mathrm{mg}, 68 \%) ;{ }^{1} \mathrm{H}$ NMR $(400 \mathrm{MHz}$, $\left.\mathrm{CDCl}_{3}\right) \delta 7.84(\mathrm{~d}, J=8.4 \mathrm{~Hz}, 1 \mathrm{H}), 7.72(\mathrm{~d}, J=8.0 \mathrm{~Hz}, 2 \mathrm{H}), 7.46(\mathrm{~d}, J$ $=8.4 \mathrm{~Hz}, 2 \mathrm{H}), 7.33(\mathrm{~d}, J=3.2 \mathrm{~Hz}, 1 \mathrm{H}), 7.30(\mathrm{~d}, J=3.6 \mathrm{~Hz}, 1 \mathrm{H}), 7.26$ $(\mathrm{s}, 1 \mathrm{H}), 7.19(\mathrm{~s}, 1 \mathrm{H}), 7.00(\mathrm{t}, J=7.6 \mathrm{~Hz}, 1 \mathrm{H}), 6.75(\mathrm{~s}, 1 \mathrm{H}), 6.43(\mathrm{~d}, J=$ $8.4 \mathrm{~Hz}, 1 \mathrm{H}) ;{ }^{13} \mathrm{C}\left\{{ }^{1} \mathrm{H}\right\}$ NMR $\left(100 \mathrm{MHz}, \mathrm{CDCl}_{3}\right) \delta 144.5,143.0,132.2$, $131.7,130.28,130.27,124.5,123.9,123.2,121.6,120.9,119.5$, 117.9, 113.4, 112.8, 112.0, 106.6; HRMS (ESI-QTOF) $\mathrm{m} / \mathrm{z}[\mathrm{M}+\mathrm{H}]^{+}$ calcd for $\mathrm{C}_{19} \mathrm{H}_{13} \mathrm{BrN}_{3}$ found 362.0287, found 362.0289.

6-(4-Bromophenyl)-9,10-dichlorobenzo[4,5]imidazo[1,2-a] pyrrolo $[2,1-c]$ pyrazine $(8 s)$.

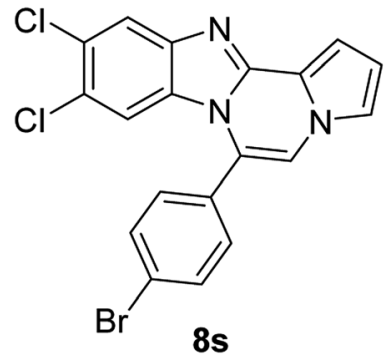

Yellow solid, mp: $266.3-266.9{ }^{\circ} \mathrm{C}(63.2 \mathrm{mg}, 78 \%) ;{ }^{1} \mathrm{H}$ NMR (400 $\left.\mathrm{MHz}, \mathrm{CDCl}_{3}\right) \delta 7.88(\mathrm{~s}, 1 \mathrm{H}), 7.76(\mathrm{~d}, J=8.4 \mathrm{~Hz}, 2 \mathrm{H}), 7.46(\mathrm{~d}, J=$ $8.0 \mathrm{~Hz}, 2 \mathrm{H}), 7.34(\mathrm{~d}, J=4.0 \mathrm{~Hz}, 1 \mathrm{H}), 7.29(\mathrm{t}, J=1.2 \mathrm{~Hz}, 1 \mathrm{H}), 7.22(\mathrm{~s}$, 1H), 6.78-6.77 (m, 1H), $6.50(\mathrm{~s}, 1 \mathrm{H}) ;{ }^{13} \mathrm{C}\left\{{ }^{1} \mathrm{H}\right\} \mathrm{NMR}\left(100 \mathrm{MHz}, \mathrm{CDCl}_{3}\right)$ $\delta$ 144.7, 144.1, 132.7, 131.7, 129.5, 128.1, 125.6, 125.4, 125.2, 122.9, 120.4, 119.2, 118.8, 114.1, 114.0, 112.8, 107.8; HRMS (ESI-QTOF) m/ $z[\mathrm{M}+\mathrm{H}]^{+}$calcd for $\mathrm{C}_{19} \mathrm{H}_{11} \mathrm{BrCl}_{2} \mathrm{~N}_{3}$ 429.9508, found 429.9507 .

6-(4-Bromophenyl)naphtho $\left[2^{\prime}, 3^{\prime}: 4,5\right]$ imidazo $[1,2-a]$ pyrrolo $[2,1-c]$ pyrazine $(8 t)$.

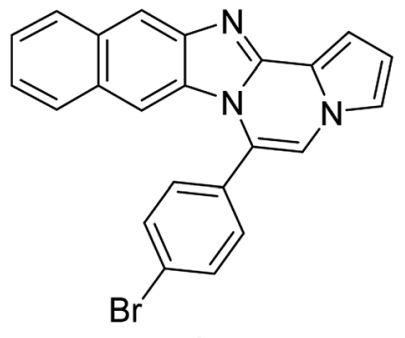

$8 t$

Brown solid, mp: $273.9-274.4{ }^{\circ} \mathrm{C}(64.4 \mathrm{mg}, 84 \%) ;{ }^{1} \mathrm{H}$ NMR $\left(400 \mathrm{MHz}, \mathrm{CDCl}_{3}\right) \delta 8.27(\mathrm{~s}, 1 \mathrm{H}), 7.95(\mathrm{~d}, J=8.0 \mathrm{~Hz}, 1 \mathrm{H}), 7.78$ $(\mathrm{d}, J=8.4 \mathrm{~Hz}, 2 \mathrm{H}), 7.58-7.52(\mathrm{~m}, 3 \mathrm{H}), 7.48(\mathrm{~d}, J=3.6 \mathrm{~Hz}, 1 \mathrm{H})$, 7.40 (t, $J=7.2 \mathrm{~Hz}, 1 \mathrm{H}), 7.34(\mathrm{~d}, J=7.6 \mathrm{~Hz}, 1 \mathrm{H}), 7.30(\mathrm{~s}, 1 \mathrm{H})$, $7.21(\mathrm{~s}, 1 \mathrm{H}), 6.80(\mathrm{~s}, 1 \mathrm{H}), 6.76(\mathrm{t}, J=3.2 \mathrm{~Hz}, 1 \mathrm{H}) ;{ }^{13} \mathrm{C}\left\{{ }^{1} \mathrm{H}\right\}$ NMR $\left(100 \mathrm{MHz}, \mathrm{CDCl}_{3}\right) \delta 132.3,131.8,131.0,130.3,129.8$, 129.3 , 128.1, 128.0, 127.8, 124.88, 124.86, 124.8, 124.4, 123.5, 119.5, 115.1, 114.2, 112.0, 109.9, 109.4, 109.3; HRMS (ESI-QTOF) $m / z[\mathrm{M}+\mathrm{H}]^{+}$calcd for $\mathrm{C}_{23} \mathrm{H}_{15} \mathrm{BrN}_{3}$ 412.0444, found 412.0445 .

6-(4-Methoxyphenyl)benzo[4,5]imidazo[1,2-a]pyrrolo[2,1-c] pyrazine $(8 u)$.

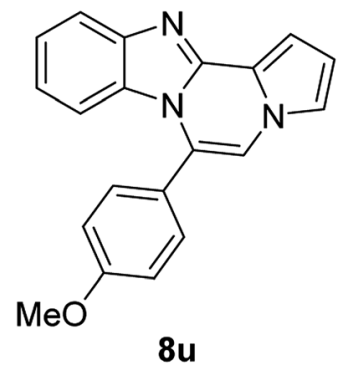

White solid, mp: $206.5-207.2{ }^{\circ} \mathrm{C}(43.0 \mathrm{mg}, 73 \%) ;{ }^{1} \mathrm{H}$ NMR (400 $\left.\mathrm{MHz} \mathrm{CDCl}_{3}\right) \delta 7.83(\mathrm{~d}, J=8.0 \mathrm{~Hz}, 1 \mathrm{H}), 7.47(\mathrm{~d}, J=8.4 \mathrm{~Hz}, 2 \mathrm{H})$, $7.32-7.28(\mathrm{~m}, 2 \mathrm{H}), 7.24(\mathrm{~s}, 1 \mathrm{H}), 7.16(\mathrm{~s}, 1 \mathrm{H}), 7.06(\mathrm{~d}, J=8.4 \mathrm{~Hz}$, $2 \mathrm{H}), 6.95(\mathrm{t}, J=7.8 \mathrm{~Hz}, 1 \mathrm{H}), 6.72(\mathrm{t}, J=3.0 \mathrm{~Hz}, 1 \mathrm{H}), 6.39(\mathrm{~d}, J=$ $8.0 \mathrm{~Hz}, 1 \mathrm{H}), 3.93(\mathrm{~s}, 3 \mathrm{H}) ;{ }^{13} \mathrm{C}\left\{{ }^{1} \mathrm{H}\right\} \mathrm{NMR}\left(100 \mathrm{MHz}, \mathrm{CDCl}_{3}\right) \delta 160.9$, 144.5 , 143.1, 131.6, 130.6, 124.1, 123.6, 123.5, 121.4, 120.9, 119.3, 117.7, 114.2, 113.1, 113.0, 111.7, 106.2, 55.5; HRMS (ESIQTOF) $m / z[\mathrm{M}+\mathrm{H}]^{+}$calcd for $\mathrm{C}_{20} \mathrm{H}_{16} \mathrm{~N}_{3} \mathrm{O} 314.1288$, found 314.1287 .

9,10-Difluoro-6-(4-methoxyphenyl)benzo[4,5]imidazo[1,2-a] pyrrolo[2,1-c]pyrazine (8v).<smiles>COc1ccc(-c2cn3cccc3c3nc4cc(F)c(F)cc4n23)cc1</smiles>

White solid, mp: $206.3-208.2{ }^{\circ} \mathrm{C}(35.3 \mathrm{mg}, 54 \%) ;{ }^{1} \mathrm{H}$ NMR (400 $\left.\mathrm{MHz}, \mathrm{CDCl}_{3}\right) \delta 7.56-7.52(\mathrm{~m}, 1 \mathrm{H}), 7.46(\mathrm{~d}, J=8.8 \mathrm{~Hz}, 2 \mathrm{H}), 7.27$ $(\mathrm{d}, J=3.6 \mathrm{~Hz}, 1 \mathrm{H}), 7.25(\mathrm{~s}, 1 \mathrm{H}), 7.18(\mathrm{~s}, 1 \mathrm{H}), 7.09(\mathrm{~d}, J=8.4 \mathrm{~Hz}$, $2 \mathrm{H}), 6.72(\mathrm{t}, J=3.0 \mathrm{~Hz}, 1 \mathrm{H}), 6.18-6.13(\mathrm{~m}, 1 \mathrm{H}), 3.95(\mathrm{~s}, 3 \mathrm{H}) ;{ }^{13} \mathrm{C}$ $\left\{{ }^{1} \mathrm{H}\right\} \mathrm{NMR}\left(100 \mathrm{MHz}, \mathrm{CDCl}_{3}\right) \delta 161.1,149.5\left(\mathrm{~d}, J_{\mathrm{C}-\mathrm{F}}=14.6 \mathrm{~Hz}\right)$, $147.2\left(\mathrm{dd}, J_{\mathrm{C}-\mathrm{F}}=39.2,15.0 \mathrm{~Hz}\right), 145.1\left(\mathrm{~d}, J_{\mathrm{C}-\mathrm{F}}=14.8 \mathrm{~Hz}\right), 144.4$, $140.0\left(\mathrm{~d}, J_{\mathrm{C}-\mathrm{F}}=10.5 \mathrm{~Hz}\right), 131.6,125.5\left(\mathrm{~d}, J_{\mathrm{C}-\mathrm{F}}=11.3 \mathrm{~Hz}\right), 123.5$, $122.5,120.5,118.0,114.5,112.6\left(\mathrm{~d}, J_{\mathrm{C}-\mathrm{F}}=120.5\right), 106.4,106.1$ $\left(\mathrm{d}, J_{\mathrm{C}-\mathrm{F}}=19.5 \mathrm{~Hz}\right), 101.2\left(\mathrm{~d}, J_{\mathrm{C}-\mathrm{F}}=24.7 \mathrm{~Hz}\right), 55.5$; HRMS (ESIQTOF) $m / z[\mathrm{M}+\mathrm{H}]^{+}$calcd for $\mathrm{C}_{20} \mathrm{H}_{14} \mathrm{~F}_{2} \mathrm{~N}_{3} \mathrm{O} 350.1099$, found 350.1095 .

9,10-Dichloro-6-(4-methoxyphenyl)benzo[4,5]imidazo[1,2-a] pyrrolo[2,1-c]pyrazine $(8 w)$. 
<smiles>COc1ccc(-c2cn3cccc3c3nc4cc(Cl)c(Cl)cc4n23)cc1</smiles>

White solid, mp: $226-227.5{ }^{\circ} \mathrm{C}(65.1 \mathrm{mg}, 91 \%) ;{ }^{1} \mathrm{H}$ NMR (400 $\left.\mathrm{MHz} \mathrm{CDCl}_{3}\right) \delta 7.84(\mathrm{~s}, 1 \mathrm{H}), 7.47(\mathrm{~d}, J=8.4 \mathrm{~Hz}, 2 \mathrm{H}), 7.30(\mathrm{~d}, J=$ $3.2 \mathrm{~Hz}, 1 \mathrm{H}), 7.26(\mathrm{~s}, 1 \mathrm{H}), 7.20(\mathrm{~s}, 1 \mathrm{H}), 7.10(\mathrm{~d}, J=8.4 \mathrm{~Hz}, 2 \mathrm{H})$, $6.74(\mathrm{t}, J=2.8 \mathrm{~Hz}, 1 \mathrm{H}), 6.44(\mathrm{~s}, 1 \mathrm{H}), 3.95(\mathrm{~s}, 3 \mathrm{H}) ;{ }^{13} \mathrm{C}\left\{{ }^{1} \mathrm{H}\right\} \mathrm{NMR}$ $\left(100 \mathrm{MHz}, \mathrm{CDCl}_{3}\right) \delta 161.2,144.5,143.9,131.5,129.6,127.6$, $124.9,123.6,122.5,120.2,119.9,118.4,114.5,114.2,113.5$, 112.3, 107.2, 55.6; HRMS (ESI-QTOF) $\mathrm{m} / \mathrm{z}[\mathrm{M}+\mathrm{H}]^{+}$calcd for $\mathrm{C}_{20} \mathrm{H}_{14} \mathrm{Cl}_{2} \mathrm{~N}_{3} \mathrm{O} 382.0508$, found 382.0504 .

9,10-Dibromo-6-(4-methoxyphenyl)benzo[4,5]imidazo[1,2-a] pyrrolo[2,1-c]pyrazine (8x).

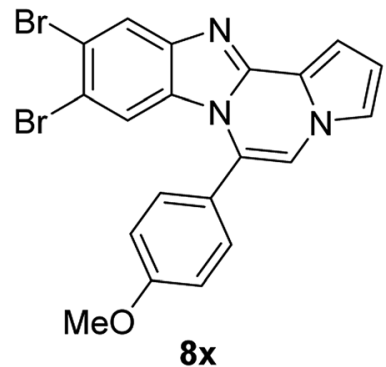

White solid, mp: $217.0-217.2{ }^{\circ} \mathrm{C}(44.8 \mathrm{mg}, 51 \%) ;{ }^{1} \mathrm{H}$ NMR (400 $\left.\mathrm{MHz}, \mathrm{CDCl}_{3}\right) \delta 8.03(\mathrm{~s}, 1 \mathrm{H}), 7.46(\mathrm{~d}, J=7.6 \mathrm{~Hz}, 2 \mathrm{H}), 7.31(\mathrm{~d}, J=$ $3.6 \mathrm{~Hz}, 1 \mathrm{H}), 7.27$ (s, 1H), 7.20 (s, 1H), 7.11 (d, $J=4.4 \mathrm{~Hz}, 2 \mathrm{H})$, $6.75(\mathrm{~s}, 1 \mathrm{H}), 6.61(\mathrm{~s}, 1 \mathrm{H}), 3.95(\mathrm{~s}, 3 \mathrm{H}) ;{ }^{13} \mathrm{C}\left\{{ }^{1} \mathrm{H}\right\}$ NMR $(100 \mathrm{MHz}$, $\left.\mathrm{CDCl}_{3}\right) \delta 161.3,144.8,144.4,131.5,130.5,123.6,123.2,122.5$, 120.2, 119.0, 118.4, 117.4, 116.2, 114.5, 113.5, 112.3, 107.3, 55.6; HRMS (ESI-QTOF) $m / z[\mathrm{M}+\mathrm{H}]^{+}$calcd for $\mathrm{C}_{20} \mathrm{H}_{14} \mathrm{Br}_{2} \mathrm{~N}_{3} \mathrm{O}$ 469.9498, found 469.9500.

6-(4-Methoxyphenyl)-9,10-dimethylbenzo[4,5]imidazo[1,2-a] pyrrolo[2,1-c]pyrazine (8y).<smiles>COc1ccc(-c2cn3cccc3c3nc4cc(C)c(C)cc4n23)cc1</smiles>

Pale yellow solid, mp: $227.1-228.1{ }^{\circ} \mathrm{C}(40.7 \mathrm{mg}, 63 \%) ;{ }^{1} \mathrm{H}$ NMR $\left(400 \mathrm{MHz}, \mathrm{CDCl}_{3}\right) \delta 7.59(\mathrm{~s}, 1 \mathrm{H}), 7.48(\mathrm{~d}, J=8.4 \mathrm{~Hz}, 2 \mathrm{H}), 7.28(\mathrm{~d}, J$ $=3.6 \mathrm{~Hz}, 1 \mathrm{H}), 7.22(\mathrm{~s}, 1 \mathrm{H}), 7.14(\mathrm{~s}, 1 \mathrm{H}), 7.08(\mathrm{~d}, J=8.4 \mathrm{~Hz}, 2 \mathrm{H})$, $6.71(\mathrm{~s}, 1 \mathrm{H}), 6.18(\mathrm{~s}, 1 \mathrm{H}), 3.95(\mathrm{~s}, 3 \mathrm{H}), 2.34(\mathrm{~s}, 3 \mathrm{H}), 2.13(\mathrm{~s}, 3 \mathrm{H})$; ${ }^{13} \mathrm{C}\left\{{ }^{1} \mathrm{H}\right\}$ NMR (100 MHz, $\left.\mathrm{CDCl}_{3}\right) \delta 160.8,143.1,142.5,132.6$, 131.6, 130.3, 129.0, 124.2, 123.8, 121.2, 119.4, 117.3, 114.1,
113.3, 112.9, 111.3, 105.6, 55.5, 20.7, 20.3; HRMS (ESI-QTOF) $\mathrm{m} /$ $z[\mathrm{M}+\mathrm{H}]^{+}$calcd for $\mathrm{C}_{22} \mathrm{H}_{20} \mathrm{~N}_{3} \mathrm{O} 342.1601$, found 342.1606.

6-(4-Methoxyphenyl)naphtho[ $\left[2^{\prime}, 3^{\prime}: 4,5\right]$ imidazo[1,2-a]pyrrolo $[2,1-c]$ pyrazine $(8 \mathrm{z})$.<smiles>COc1ccc(-c2cn3cccc3c3nc4cc5ccccc5cc4n23)cc1</smiles>

Brown solid, mp: $230.2-231.2{ }^{\circ} \mathrm{C}(55.3 \mathrm{mg}, 81 \%) ;{ }^{1} \mathrm{H}$ NMR $(400$ $\left.\mathrm{MHz} \mathrm{CDCl}_{3}\right) \delta 8.24(\mathrm{~s}, 1 \mathrm{H}), 7.95(\mathrm{~d}, J=8.4 \mathrm{~Hz}, 1 \mathrm{H}), 7.55(\mathrm{t}, J=$ $8.2 \mathrm{~Hz}, 3 \mathrm{H}), 7.42(\mathrm{~d}, J=2.8 \mathrm{~Hz}, 1 \mathrm{H}), 7.38(\mathrm{t}, J=8.4 \mathrm{~Hz}, 1 \mathrm{H}), 7.31$ $(\mathrm{d}, J=7.2 \mathrm{~Hz}, 1 \mathrm{H}), 7.28(\mathrm{~s}, 1 \mathrm{H}), 7.16(\mathrm{~s}, 1 \mathrm{H}), 7.12(\mathrm{~d}, J=8.0 \mathrm{~Hz}$, 2H), $6.80(\mathrm{~s}, 1 \mathrm{H}), 6.75(\mathrm{~s}, 1 \mathrm{H}), 3.98(\mathrm{~s}, 3 \mathrm{H}) ;{ }^{13} \mathrm{C}\left\{{ }^{1} \mathrm{H}\right\}$ NMR $(100$ $\left.\mathrm{MHz}, \mathrm{CDCl}_{3}\right) \delta 161.0,146.1,144.3,131.7,131.3,130.8,129.2$, $128.0,127.8,124.6,124.1,123.8,123.4,120.5,118.6,115.4$, 114.3, 113.3, 111.0, 109.8, 107.9, 55.6; HRMS (ESI-QTOF) $\mathrm{m} / z$ [M $+\mathrm{H}]^{+}$calcd for $\mathrm{C}_{24} \mathrm{H}_{18} \mathrm{~N}_{3} \mathrm{O}$ 364.1444, found 364.1448.

6-(2,5-Dimethoxyphenyl)benzo[4,5]imidazo[1,2-a]pyrrolo [2,1-c]pyrazine (8aa).<smiles>COc1ccc(OC)c(-c2cn3cccc3c3nc4ccccc4n23)c1</smiles>

White solid, mp: $187.3-188.2{ }^{\circ} \mathrm{C}(50.6 \mathrm{mg}, 78 \%) ;{ }^{1} \mathrm{H}$ NMR (400 $\left.\mathrm{MHz}, \mathrm{CDCl}_{3}\right) \delta 7.83(\mathrm{~d}, J=8.0 \mathrm{~Hz}, 1 \mathrm{H}), 7.34-7.28(\mathrm{~m}, 2 \mathrm{H}), 7.26$ (s, 1H), 7.23 (s, 1H), 7.16-7.15 (m, 1H), 7.04-6.94 (m, 3H), $6.74(\mathrm{t}$, $J=3.2 \mathrm{~Hz}, 1 \mathrm{H}), 6.44(\mathrm{~d}, J=8.0 \mathrm{~Hz}, 1 \mathrm{H}), 3.83(\mathrm{~s}, 3 \mathrm{H}), 3.58(\mathrm{~s}, 3 \mathrm{H})$; ${ }^{13} \mathrm{C}\left\{{ }^{1} \mathrm{H}\right\}$ NMR $\left(100 \mathrm{MHz}, \mathrm{CDCl}_{3}\right) \delta 153.6,153.0,144.3,142.9$, 130.9, 123.5, 121.6, 121.4, 121.1, 120.9, 119.2, 117.7, 117.6, 116.6, 113.0, 112.1, 111.9, 111.86, 106.1, 55.9, 55.88; HRMS (ESIQTOF) $m / z[\mathrm{M}+\mathrm{Na}]^{+}$calcd for $\mathrm{C}_{21} \mathrm{H}_{17} \mathrm{~N}_{3} \mathrm{NaO}_{2} 366.1213$, found 366.1211.

6-(2,5-Dimethoxyphenyl)naphtho[ $\left[2^{\prime}, 3^{\prime}: 4,5\right]$ imidazo[ $\left.1,2-a\right]$ pyrrolo[2,1-c]pyrazine (8ab).

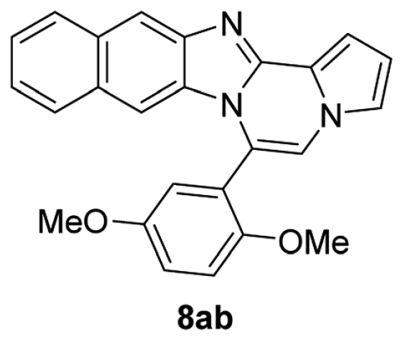

Pale brown solid, mp: $186.5-187.2{ }^{\circ} \mathrm{C}(60.0 \mathrm{mg}, 81 \%) ;{ }^{1} \mathrm{H}$ NMR 
$\left(400 \mathrm{MHz}, \mathrm{CDCl}_{3}\right) \delta 8.25(\mathrm{~s}, 1 \mathrm{H}), 7.97(\mathrm{~d}, J=8.4 \mathrm{~Hz}, 1 \mathrm{H}), 7.56(\mathrm{~d}, J$ $=8.0 \mathrm{~Hz}, 1 \mathrm{H}), 7.44(\mathrm{~d}, J=3.6 \mathrm{~Hz}, 1 \mathrm{H}), 7.38(\mathrm{t}, J=7.4 \mathrm{~Hz}, 1 \mathrm{H})$, $7.31-7.28(\mathrm{~m}, 2 \mathrm{H}), 7.23(\mathrm{~s}, 1 \mathrm{H}), 7.21(\mathrm{~d}, J=2.8 \mathrm{~Hz}, 1 \mathrm{H}), 7.10(\mathrm{~d}, J$ $=2.8 \mathrm{~Hz}, 1 \mathrm{H}), 7.05(\mathrm{~d}, J=9.2 \mathrm{~Hz}, 1 \mathrm{H}), 6.83(\mathrm{~s}, 1 \mathrm{H}), 6.77(\mathrm{t}, J=$ $2.6 \mathrm{~Hz}, 1 \mathrm{H}), 3.86(\mathrm{~s}, 3 \mathrm{H}), 3.54(\mathrm{~s}, 3 \mathrm{H}) ;{ }^{13} \mathrm{C}\left\{{ }^{1} \mathrm{H}\right\} \mathrm{NMR}(100 \mathrm{MHz}$, $\left.\mathrm{CDCl}_{3}\right) \delta 153.7,153.1,145.9,144.2$, 131.6, 130.9, 129.5, 127.9, $127.8,124.0,123.6,121.9,120.8,120.6,118.6$, 117.7, 116.8, 115.2, 113.2, 111.9, 111.2, 108.7, 107.8, 56.0, 55.9; HRMS (ESIQTOF) $m / z[\mathrm{M}+\mathrm{H}]^{+}$calcd for $\mathrm{C}_{25} \mathrm{H}_{20} \mathrm{~N}_{3} \mathrm{O}_{2} 394.1550$, found 394.1552 .

6-([1,1'-Biphenyl $]-4-y l)$ benzo $[4,5]$ imidazo $[1,2-a]$ pyrrolo $[2,1-c]$ pyrazine (8ac).

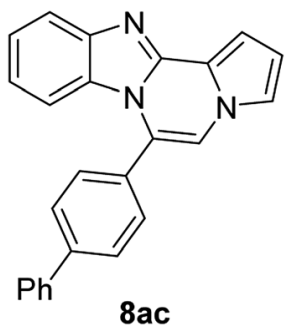

Pale yellow solid, mp: $177.0-177.7{ }^{\circ} \mathrm{C}(57.6 \mathrm{mg}, 85 \%) ;{ }^{1} \mathrm{H}$ NMR $\left(400 \mathrm{MHz}, \mathrm{CDCl}_{3}\right) \delta 7.86(\mathrm{~d}, J=8.4 \mathrm{~Hz}, 1 \mathrm{H}), 7.82(\mathrm{~d}, J=7.6 \mathrm{~Hz}$, $2 \mathrm{H}), 7.75(\mathrm{~d}, J=8.0 \mathrm{~Hz}, 2 \mathrm{H}), 7.66(\mathrm{~d}, J=7.6 \mathrm{~Hz}, 2 \mathrm{H}), 7.53(\mathrm{t}, J=$ $7.6 \mathrm{~Hz}, 2 \mathrm{H}), 7.45$ (d, $J=7.6 \mathrm{~Hz}, 1 \mathrm{H}), 7.36(\mathrm{~d}, J=4.0 \mathrm{~Hz}, 1 \mathrm{H})$, $7.33-7.29(\mathrm{~m}, 3 \mathrm{H}), 6.97(\mathrm{t}, J=7.8 \mathrm{~Hz}, 1 \mathrm{H}), 6.76(\mathrm{t}, J=2.8 \mathrm{~Hz}, 1 \mathrm{H})$, $6.53(\mathrm{~d}, J=8.4 \mathrm{~Hz}, 1 \mathrm{H}) ;{ }^{13} \mathrm{C}\left\{{ }^{1} \mathrm{H}\right\} \mathrm{NMR}\left(100 \mathrm{MHz}, \mathrm{CDCl}_{3}\right) \delta 144.6$, $143.1,142.9$, 139.9, 130.6, 130.5, 130.2, 129.0, 128.0, 127.5, $127.1,127.0,124.1,123.7,121.5,121.0,119.4,117.8,113.2$, 113.1, 111.8, 106.4; HRMS (ESI-QTOF) $m / z[\mathrm{M}+\mathrm{H}]^{+}$calcd for $\mathrm{C}_{25} \mathrm{H}_{18} \mathrm{~N}_{3}$ 360.1495, found 360.1499.

6-([1,1'-Biphenyl]-4-yl)-9,10-dichlorobenzo[4,5]imidazo[1,2$a]$ pyrrolo[2,1-c]pyrazine (8ad).

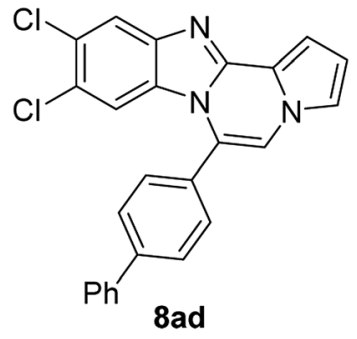

Pale yellow solid, mp: 253.2-254.6 ${ }^{\circ} \mathrm{C}(46.4 \mathrm{mg}, 58 \%) ;{ }^{1} \mathrm{H}$ NMR (400 MHz, $\left.\mathrm{CDCl}_{3}\right) \delta 7.87(\mathrm{~s}, 1 \mathrm{H}), 7.83(\mathrm{~d}, J=8.0 \mathrm{~Hz}$, $2 \mathrm{H}), 7.73(\mathrm{~d}, J=7.2 \mathrm{~Hz}, 2 \mathrm{H}), 7.63(\mathrm{~d}, J=8.0 \mathrm{~Hz}, 2 \mathrm{H}), 7.53(\mathrm{t}, J$ $=7.6 \mathrm{~Hz}, 2 \mathrm{H}), 7.46(\mathrm{~d}, J=7.2 \mathrm{~Hz}, 1 \mathrm{H}), 7.34(\mathrm{~d}, J=3.2 \mathrm{~Hz}$, $1 \mathrm{H}), 7.28(\mathrm{~d}, J=8.4 \mathrm{~Hz}, 2 \mathrm{H}), 6.77(\mathrm{~s}, 1 \mathrm{H}), 6.53(\mathrm{~s}, 1 \mathrm{H}) ;{ }^{13} \mathrm{C}$ $\left\{{ }^{1} \mathrm{H}\right\}$ NMR $\left(100 \mathrm{MHz}, \mathrm{CDCl}_{3}\right) \delta 144.6,144.0,143.5,139.8$, $130.5,129.5$, 129.2, 129.0, 128.2, 127.8, 127.2, 125.0, 123.6, 120.3, 120.1, 118.5, 114.3, 113.6, 112.4, 107.4; HRMS (ESIQTOF) $m / z[\mathrm{M}+\mathrm{H}]^{+}$calcd for $\mathrm{C}_{25} \mathrm{H}_{16} \mathrm{Cl}_{2} \mathrm{~N}_{3} 428.0716$, found 428.0719.

6-([1,1'-biphenyl]-4-yl)naphtho $\left[2^{\prime}, 3^{\prime}: 4,5\right]$ imidazo $[1,2-a]$ pyrrolo[2,1-c]pyrazine (8ae).

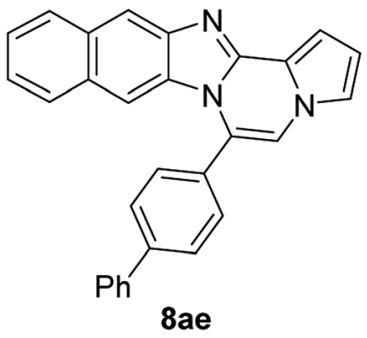

Brown solid, mp: $246.6-245.2{ }^{\circ} \mathrm{C}(48.3 \mathrm{mg}, 63 \%) ;{ }^{1} \mathrm{H}$ NMR (400 $\left.\mathrm{MHz} \mathrm{CDCl}_{3}\right) \delta 8.27(\mathrm{~s}, 1 \mathrm{H}), 7.97(\mathrm{~d}, J=8.4 \mathrm{~Hz}, 1 \mathrm{H}), 7.86(\mathrm{~d}, J=$ $7.6 \mathrm{~Hz}, 2 \mathrm{H}), 7.78(\mathrm{~d}, J=7.2 \mathrm{~Hz}, 2 \mathrm{H}), 7.72(\mathrm{~d}, J=8.0 \mathrm{~Hz}, 2 \mathrm{H}), 7.56$ $(\mathrm{t}, J=7.8 \mathrm{~Hz}, 2 \mathrm{H}), 7.52-7.45(\mathrm{~m}, 3 \mathrm{H}), 7.38(\mathrm{t}, J=7.4 \mathrm{~Hz}, 1 \mathrm{H}), 7.32$ $(\mathrm{s}, 1 \mathrm{H}), 7.29(\mathrm{~d}, J=7.2 \mathrm{~Hz}, 1 \mathrm{H}), 7.25(\mathrm{~s}, 1 \mathrm{H}), 6.88(\mathrm{~s}, 1 \mathrm{H}), 6.79(\mathrm{t}, J$ $=3.2 \mathrm{~Hz}, 1 \mathrm{H}) ;{ }^{13} \mathrm{C}\left\{{ }^{1} \mathrm{H}\right\} \mathrm{NMR}\left(100 \mathrm{MHz}, \mathrm{CDCl}_{3}\right) \delta 146.1,144.4$, 143.0, 140.0, 131.2, 130.9, 130.6, 130.1, 129.2, 129.1, 128.1, $128.0,127.8,127.5,127.2$, 124.6, 124.2, 123.9, 120.6, 118.8, 115.5, 113.4, 111.2, 109.8, 108.0; HRMS (ESI-QTOF) $m / z[\mathrm{M}+\mathrm{H}]^{+}$ calcd for $\mathrm{C}_{29} \mathrm{H}_{20} \mathrm{~N}_{3} 410.1652$, found 410.1651 .

6-(Naphthalen-2-yl)benzo[4,5]imidazo[1,2-a]pyrrolo[2,1-c] pyrazine (8af).

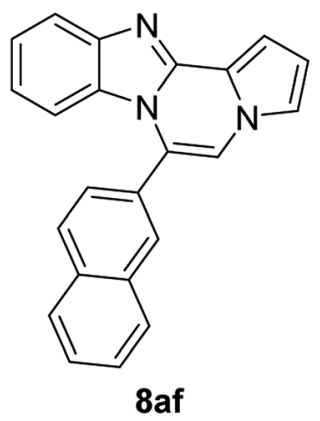

Pale yellow solid, mp: $165.9-166.3{ }^{\circ} \mathrm{C}(47.8 \mathrm{mg}, 75 \%) ;{ }^{1} \mathrm{H}$ NMR $\left(400 \mathrm{MHz}, \mathrm{CDCl}_{3}\right) \delta 8.13(\mathrm{~s}, 1 \mathrm{H}), 8.06-8.00(\mathrm{~m}, 2 \mathrm{H}) 7.94(\mathrm{~d}, J=$ $9.2 \mathrm{~Hz}, 2 \mathrm{H}), 7.70-7.61(\mathrm{~m}, 3 \mathrm{H}), 7.53(\mathrm{~s}, 1 \mathrm{H}), 7.39(\mathrm{~s}, 1 \mathrm{H}), 7.37$ (s, $1 \mathrm{H}), 7.32(\mathrm{t}, J=7.8 \mathrm{~Hz}, 1 \mathrm{H}), 6.91(\mathrm{t}, J=7.8 \mathrm{~Hz}, 1 \mathrm{H}), 6.82(\mathrm{~s}, 1 \mathrm{H})$, $6.39(\mathrm{~d}, J=7.2 \mathrm{~Hz}, 1 \mathrm{H}) ;{ }^{13} \mathrm{C}\left\{{ }^{1} \mathrm{H}\right\} \mathrm{NMR}\left(100 \mathrm{MHz}, \mathrm{CDCl}_{3}\right) \delta 138.7$, 133.8, 133.0, 129.9, 129.6, 128.8, 128.4, 128.17, 128.15, 128.0, $127.7,127.3$, 127.1, 127.08, 124.6, 124.59, 124.2, 122.3, 118.7, 118.5, 114.1, 113.4, 112.9; HRMS (ESI-QTOF) $m / z[\mathrm{M}+\mathrm{H}]^{+}$calcd for $\mathrm{C}_{23} \mathrm{H}_{16} \mathrm{~N}_{3}$ 334.1339, found 334.1332.

9,10-Dichloro-6-(naphthalen-2-yl)benzo[4,5]imidazo[1,2-a] pyrrolo[2,1-c]pyrazine (8ag).

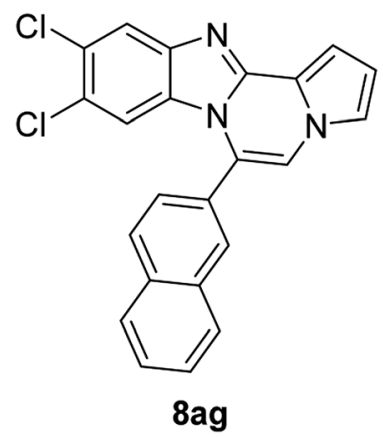

White solid, mp: $273.3-273.8{ }^{\circ} \mathrm{C}(42.7 \mathrm{mg}, 57 \%) ;{ }^{1} \mathrm{H}$ NMR (400 $\left.\mathrm{MHz} \mathrm{CDCl}_{3}\right) \delta 8.10(\mathrm{~s}, 1 \mathrm{H}), 8.06(\mathrm{~d}, J=8.4 \mathrm{~Hz}, 1 \mathrm{H}), 8.02(\mathrm{~d}, J=$ 
$7.6 \mathrm{~Hz}, 1 \mathrm{H}), 7.96(\mathrm{~d}, J=7.2 \mathrm{~Hz}, 1 \mathrm{H}), 7.89(\mathrm{~d}, J=1.6 \mathrm{~Hz}, 1 \mathrm{H}), 7.66$ $(\mathrm{t}, J=5.8 \mathrm{~Hz}, 2 \mathrm{H}), 7.59(\mathrm{~d}, J=8.4 \mathrm{~Hz}, 1 \mathrm{H}), 7.37(\mathrm{~s}, 1 \mathrm{H}), 7.32(\mathrm{~s}$, $2 \mathrm{H}), 6.78(\mathrm{~d}, J=2.8 \mathrm{~Hz}, 1 \mathrm{H}), 6.50(\mathrm{~d}, J=1.2 \mathrm{~Hz}, 1 \mathrm{H}) ;{ }^{13} \mathrm{C}\left\{{ }^{1} \mathrm{H}\right\}$ NMR (100 MHz, $\left.\mathrm{CDCl}_{3}\right) \delta$ 144.6, 144.0, 133.8, 133.0, 129.6, 129.4, 128.9, 128.8, 128.3, 128.1, 127.8, 127.76, 127.7, 127.4, 126.7, 125.0, 124.0, 120.1 118.5, 114.3, 113.7, 112.7, 107.4; HRMS (ESIQTOF) $m / z[\mathrm{M}+\mathrm{H}]^{+}$calcd for $\mathrm{C}_{23} \mathrm{H}_{14} \mathrm{Cl}_{2} \mathrm{~N}_{3}$ 402.0599, found 402.0593.

6-(Naphthalen-2-yl)naphtho $\left[2^{\prime}, 3^{\prime}: 4,5\right]$ imidazo $[1,2-a]$ pyrrolo $[2,1-c]$ pyrazine (8ah).

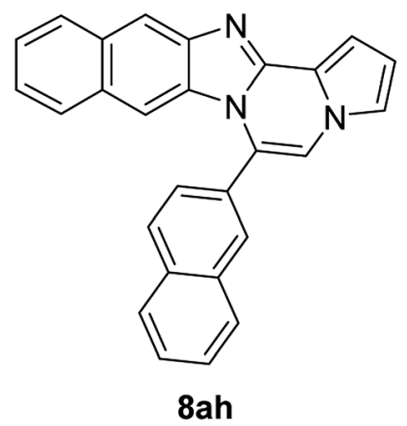

Yellow solid, mp: $151-152{ }^{\circ} \mathrm{C}(57.0 \mathrm{mg}, 79 \%) ;{ }^{1} \mathrm{H}$ NMR $(400$ MHz, DMSO-d $\left.{ }_{6}\right) \delta 8.39(\mathrm{~s}, 1 \mathrm{H}), 8.25(\mathrm{~s}, 1 \mathrm{H}), 8.21(\mathrm{~d}, J=8.4 \mathrm{~Hz}$, $1 \mathrm{H}), 8.17(\mathrm{~d}, J=7.6 \mathrm{~Hz}, 1 \mathrm{H}), 8.10(\mathrm{~d}, J=8.0 \mathrm{~Hz}, 1 \mathrm{H}), 7.99(\mathrm{~d}, J=$ $8.4 \mathrm{~Hz}, 1 \mathrm{H}), 7.96(\mathrm{~s}, 1 \mathrm{H}), 7.85(\mathrm{~d}, J=8.4 \mathrm{~Hz}, 1 \mathrm{H}) 7.76-7.68(\mathrm{~m}$, $3 \mathrm{H}), 7.36(\mathrm{t}, J=7.2 \mathrm{~Hz}, 1 \mathrm{H}), 7.32$ (d, $J=3.2 \mathrm{~Hz}, 1 \mathrm{H}), 7.28-7.21$ $(\mathrm{m}, 2 \mathrm{H}), 6.84-6.82(\mathrm{~m}, 1 \mathrm{H}), 6.70(\mathrm{~s}, 1 \mathrm{H}) ;{ }^{13} \mathrm{C}\left\{{ }^{1} \mathrm{H}\right\} \mathrm{NMR}(100 \mathrm{MHz}$, DMSO-d $\left._{6}\right) \delta 146.1,144.6,135.6,133.8,133.1,130.7,129.7,129.0$, $128.8,128.79,128.7,128.4,128.0,127.9$, 127.6, 124.6, 124.4, $124.3,120.6,120.1,115.2$, 113.6, 112.5, 109.6, 109.0, 108.9, 107.9; HRMS (ESI-QTOF) $m / z[\mathrm{M}+\mathrm{H}]^{+}$calcd for $\mathrm{C}_{27} \mathrm{H}_{18} \mathrm{~N}_{3}$ 384.1495, found 384.1494.

6-Methylbenzo[4,5]imidazo[1,2-a]pyrrolo[2,1-c]pyrazine (8ai).

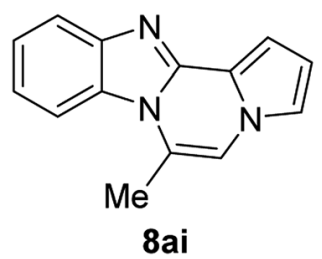

Brown solid, mp: $153.4-153.6{ }^{\circ} \mathrm{C}(33.6 \mathrm{mg}, 80 \%) ;{ }^{1} \mathrm{H}$ NMR (400 $\left.\mathrm{MHz} \mathrm{CDCl}_{3}\right) \delta 7.86(\mathrm{~d}, J=8.0 \mathrm{~Hz}, 1 \mathrm{H}), 7.81(\mathrm{~d}, J=8.4 \mathrm{~Hz}, 1 \mathrm{H})$, $7.36(\mathrm{t}, J=7.6 \mathrm{~Hz}, 1 \mathrm{H}), 7.25-7.20(\mathrm{~m}, 2 \mathrm{H}), 7.13(\mathrm{t}, J=1.2 \mathrm{~Hz}, 1 \mathrm{H})$, $6.99(\mathrm{~s}, 1 \mathrm{H}), 6.65(\mathrm{t}, J=3.0 \mathrm{~Hz}, 1 \mathrm{H}), 2.75(\mathrm{~s}, 3 \mathrm{H}) ;{ }^{13} \mathrm{C}\left\{{ }^{1} \mathrm{H}\right\} \mathrm{NMR}$ $\left(100 \mathrm{MHz}, \mathrm{CDCl}_{3}\right) \delta 139.3,137.9,125.9,118.5,116.6,115.4$, 115.3, 114.3, 111.8, 107.3, 107.29, 104.5, 100.7, 12.5; HRMS (ESIQTOF) $m / z[\mathrm{M}+\mathrm{H}]^{+}$calcd for $\mathrm{C}_{14} \mathrm{H}_{12} \mathrm{~N}_{3}$ 222.1026, found 222.1025 .

Compounds $\mathbf{9}, \mathbf{1 1}$, and $\mathbf{1 3}$ were synthesized by following the same procedure for the synthesis of $\mathbf{8}$ except that a higher reaction temperature was needed in case of 9 .

Benzo[4,5]imidazo[1,2-a]pyrrolo[2,1-c]pyrazine (9).

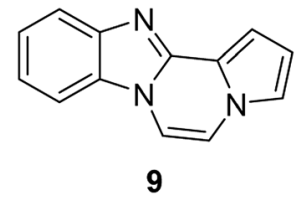

Pale yellow solid, mp: $148-148.9{ }^{\circ} \mathrm{C}(10.5 \mathrm{mg}, 21 \%) ;{ }^{1} \mathrm{H}$ NMR $\left(400 \mathrm{MHz}, \mathrm{CDCl}_{3}\right) \delta 7.87(\mathrm{~d}, J=8.0 \mathrm{~Hz}, 1 \mathrm{H}), 7.59(\mathrm{~d}, J=7.6 \mathrm{~Hz}$, 1H), 7.42-7.30 (m, 6H), $6.71(\mathrm{~d}, J=1.6 \mathrm{~Hz}, 1 \mathrm{H}) ;{ }^{13} \mathrm{C}\left\{{ }^{1} \mathrm{H}\right\} \mathrm{NMR}$ $\left(100 \mathrm{MHz}, \mathrm{CDCl}_{3}\right) \delta 144.1,142.5,141.9,130.0,124.1,122.0$, 119.5, 118.3, 113.0, 112.4, 109.0, 108.2, 106.6; HRMS (ESI-QTOF) $m / z[\mathrm{M}+\mathrm{H}]^{+}$calcd for $\mathrm{C}_{13} \mathrm{H}_{10} \mathrm{~N}_{3} 208.0869$, found 208.0868 .

7-Phenylbenzo $\left[4^{\prime}, 5^{\prime}\right]$ imidazo $\left[2^{\prime}, 1^{\prime}: 3,4\right]$ pyrazino $[1,2-a]$ indole (11).

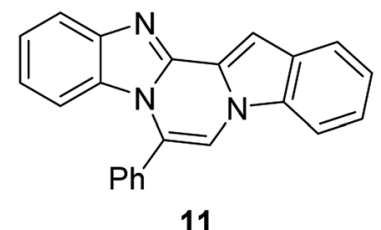

Pale yellow solid, mp: $189.7-190.2{ }^{\circ} \mathrm{C}$ (62.7 mg, 100\%); ${ }^{1} \mathrm{H}$ NMR $\left(400 \mathrm{MHz}, \mathrm{CDCl}_{3}\right) \delta 7.91(\mathrm{t}, J=7.2 \mathrm{~Hz}, 2 \mathrm{H}), 7.71(\mathrm{~d}, J=5.6 \mathrm{~Hz}$, $1 \mathrm{H}), 7.66-7.59(\mathrm{~m}, 6 \mathrm{H}), 7.52(\mathrm{~d}, J=2.8 \mathrm{~Hz}, 1 \mathrm{H}), 7.42-7.31(\mathrm{~m}$, 3H), 7.03-6.99 (m, 1H), $6.43(\mathrm{~d}, J=8.4 \mathrm{~Hz}, 1 \mathrm{H}) ;{ }^{13} \mathrm{C}\left\{{ }^{1} \mathrm{H}\right\} \mathrm{NMR}$ $\left(100 \mathrm{MHz}, \mathrm{CDCl}_{3}\right) \delta 144.4,142.7,132.4,131.6,130.8,130.4$, $130.1,128.9$, 128.8, 125.2, 123.8, 123.2, 122.7, 122.4, 122.3, 122.0, 119.8, 113.2, 109.8, 109.5, 99.1; HRMS (ESI-QTOF) $m / z$ [M $+\mathrm{H}]^{+}$calcd for $\mathrm{C}_{23} \mathrm{H}_{16} \mathrm{~N}_{3} 334.1339$, found 334.1334.

5-Methyl-6-phenylbenzo[4,5]imidazo[1,2-a]pyrrolo[2,1-c]pyrazine (13a).<smiles>Cc1c(-c2ccccc2)n2cccc2c2nc3ccccc3n12</smiles>

$13 a$

Pale yellow solid, mp: $188.0-188.6{ }^{\circ} \mathrm{C}(41.1 \mathrm{mg}, 74 \%) ;{ }^{1} \mathrm{H}$ NMR $\left(400 \mathrm{MHz}, \mathrm{CDCl}_{3}\right) \delta 7.81(\mathrm{~d}, J=8.0 \mathrm{~Hz}, 1 \mathrm{H}), 7.68-7.63(\mathrm{~m}, 3 \mathrm{H})$, $7.51(\mathrm{~d}, J=6.4 \mathrm{~Hz}, 2 \mathrm{H}), 7.43(\mathrm{~s}, 1 \mathrm{H}), 7.34(\mathrm{~s}, 1 \mathrm{H}), 7.24(\mathrm{~s}, 1 \mathrm{H})$, 6.88-6.82 (m, 2H), $5.87(\mathrm{~d}, J=8.4 \mathrm{~Hz}, 1 \mathrm{H}), 2.32(\mathrm{~s}, 3 \mathrm{H}) ;{ }^{13} \mathrm{C}\left\{{ }^{1} \mathrm{H}\right\}$ NMR (100 MHz, $\mathrm{CDCl}_{3}$ ) 144.2, 142.5, 132.0, 131.2, 130.6, 130.1, $129.4,128.9,126.7,123.5,121.3,121.1,120.7,119.0,117.8$, 115.8, 113.1, 112.7, 106.8, 14.3; HRMS (ESI-QTOF) $m / z[\mathrm{M}+\mathrm{Na}]^{+}$ calcd for $\mathrm{C}_{20} \mathrm{H}_{15} \mathrm{~N}_{3} \mathrm{Na} 320.1158$, found 320.1157 .

5-Benzyl-6-phenylbenzo[4,5]imidazo[1,2-a]pyrrolo[2,1-c]pyrazine (13b).<smiles>c1ccc(Cc2c(-c3ccccc3)n3cccc3c3nc4ccccc4n23)cc1</smiles>

$13 b$

Yellow solid, mp: $183.1-183.5{ }^{\circ} \mathrm{C}(40.6 \mathrm{mg}, 81 \%) ;{ }^{1} \mathrm{H}$ NMR (400 
$\left.\mathrm{MHz}, \mathrm{CDCl}_{3}\right) \delta 7.86(\mathrm{~d}, J=8.0 \mathrm{~Hz}, 1 \mathrm{H}), 7.66(\mathrm{~d}, J=6.8 \mathrm{~Hz}, 1 \mathrm{H})$, $7.63-7.57(\mathrm{~m}, 4 \mathrm{H}), 7.42(\mathrm{~d}, J=2.8 \mathrm{~Hz}, 1 \mathrm{H}), 7.34-7.29(\mathrm{~m}, 4 \mathrm{H})$, $7.22(\mathrm{~d}, J=7.2 \mathrm{~Hz}, 2 \mathrm{H}), 7.13(\mathrm{~s}, 1 \mathrm{H}), 6.91(\mathrm{t}, J=7.8 \mathrm{~Hz}, 1 \mathrm{H}), 6.68$ $(\mathrm{s}, 1 \mathrm{H}), 5.88(\mathrm{~d}, J=7.6 \mathrm{~Hz}, 1 \mathrm{H}), 4.12(\mathrm{~s}, 2 \mathrm{H}) ;{ }^{13} \mathrm{C}\left\{{ }^{1} \mathrm{H}\right\} \mathrm{NMR}(100$ $\mathrm{MHz}, \mathrm{CDCl}_{3}$ ) 144.4, 142.6, 136.4, 131.6, 130.9, 130.7, 130.3, 129.5 , 129.0, 127.4, 127.0, 123.6, 122.7, 121.2, 119.3, 119.2, 117.2, 113.0, 112.7, 106.6, 34.0; HRMS (ESI-QTOF) $m / z[\mathrm{M}+\mathrm{Na}]^{+}$ calcd for $\mathrm{C}_{26} \mathrm{H}_{19} \mathrm{~N}_{3} \mathrm{Na} 396.1471$, found 396.1477.

\section{Synthesis of 14}

After a mixture of $8 \mathrm{a}(0.0388 \mathrm{mmol})$ and iodomethane $(0.5 \mathrm{~mL})$ in $\mathrm{CH}_{2} \mathrm{Cl}_{2}(0.5 \mathrm{~mL})$ was stirred at $\mathrm{rt}$ for $3 \mathrm{~h}$, the reaction mixture was concentrated under reduced pressure to give $14(23.8 \mathrm{mg}$, $100 \%)$.

12-Methyl-6-phenylbenzo[4,5]imidazo[1,2-a]pyrrolo[2,1-c] pyrazin-12-ium iodide (14).

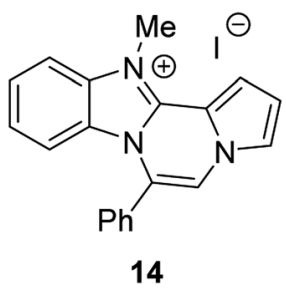

Yellow solid, mp: $297-298{ }^{\circ} \mathrm{C}(23.8 \mathrm{mg}, 100 \%) ;{ }^{1} \mathrm{H}$ NMR (400 MHz, DMSO-d $\left.{ }_{6}\right) \delta 8.43(\mathrm{~s}, 1 \mathrm{H}), 8.14-8.13(\mathrm{~m}, 2 \mathrm{H}), 7.95(\mathrm{~d}, J=$ $4.0 \mathrm{~Hz}, 1 \mathrm{H}), 7.70-7.61(\mathrm{~m}, 6 \mathrm{H}), 7.29(\mathrm{t}, J=8.0 \mathrm{~Hz}, 1 \mathrm{H}), 7.20-7.18$ $(\mathrm{m}, 1 \mathrm{H}), 6.24(\mathrm{~d}, J=8.8 \mathrm{~Hz}, 1 \mathrm{H}), 4.37(\mathrm{~s}, 3 \mathrm{H}) ;{ }^{13} \mathrm{C}\left\{{ }^{1} \mathrm{H}\right\} \mathrm{NMR}(100$ MHz, DMSO-d $\left.\mathrm{d}_{6}\right) \delta 139.0,133.1,131.6,131.0,129.85,129.82$, $127.7,127.2$, 125.4, 123.5, 123.3, 116.8, 116.4, 114.7, 114.2, 113.2, 112.6, 33.1; HRMS (ESI-QTOF) $\mathrm{m} / \mathrm{z}[\mathrm{M}+\mathrm{H}]^{+}$calcd for $\mathrm{C}_{20} \mathrm{H}_{16} \mathrm{~N}_{3}$ 298.1339, found 298.1340.

\section{Conflicts of interest}

There are no conflicts to declare.

\section{Acknowledgements}

This work was supported by the National Research Foundation of Korea (NRF) grant funded by the Korea government (MSIP) (NRF-2017R1A2A2A05069364 and NRF-2018R1A6A1A03023718) to I. K. and the National Research Foundation of Korea (NRF) grants funded by the Korean government (MSIP) (NRF2018R1A2B2005535 and 2018R1A4A1021703) to J. L. We acknowledge Ounyoung Lim for contribution in Operetta HighContent imaging data.

\section{References}

1 M. Beija, C. A. Afonso and J. M. Martinho, Chem. Soc. Rev., 2009, 38, 2410-2433.

2 Z. Guo, S. Park, J. Yoon and I. Shin, Chem. Soc. Rev., 2014, 43, 16-29.

3 L. Yuan, W. Lin, K. Zheng, L. He and W. Huang, Chem. Soc. Rev., 2013, 42, 622-661.
4 T. Kowada, H. Maeda and K. Kikuchi, Chem. Soc. Rev., 2015, 44, 4953-4972.

5 W. Z. Yuan, P. Lu, S. Chen, J. W. Y. Lam, Z. Wang, Y. Liu, H. S. Kwok, Y. Ma and B. Z. Tang, Adv. Mater., 2010, 22, 2159-2163.

6 M. Huang, R. Yu, K. Xu, S. Ye, S. Kuang, X. Zhu and Y. Wan, Chem. Sci., 2016, 7, 4485-4491.

7 Y. Hong, J. W. Y. Lam and B. Z. Tang, Chem. Soc. Rev., 2011, 40, 5361-5388.

8 J. Mei, N. L. Leung, R. T. Kwok, J. W. Lam and B. Z. Tang, Chem. Rev., 2015, 115, 11718-11940.

9 C. Maeda, K. Nagahata and T. Ema, Org. Biomol. Chem., 2017, 15, 7783-7788.

10 Y. Liu, Y. Zhang, X. Wu, Q. Lan, C. Chen, S. Liu, Z. Chi, L. Jiang, X. Chen and J. Xu, J. Mater. Chem. C, 2014, 2, 1068-1075.

11 J. Yang, J. Huang, Q. Li and Z. Li, J. Mater. Chem. C, 2016, 4, 2663-2684.

12 D. Lo, C.-H. Chang, G. Krucaite, D. Volyniuk, J. V. Grazulevicius and S. Grigalevicius, J. Mater. Chem. C, 2017, 5, 6054-6060.

13 J. Huang, N. Sun, P. Chen, R. Tang, Q. Li, D. Ma and Z. Li, Chem. Commun., 2014, 50, 2136-2138.

14 S. Kwon, D. I. Kwon, Y. Jung, J. H. Kim, Y. Lee, B. Lim, I. Kim and J. Lee, Sens. Actuators, B, 2017, 252, 340-352.

15 D. K. Singh, K. Jang, J. Kim, J. Lee and I. Kim, ACS Comb. Sci., 2019, 21, 408-416.

16 D. Aakash, B. Richa Kaur, K. Ramanjot, K. Sanjiv, J. Upendra Kumar, S. Harinder, B. Sandeep, K. Dinesh and D. Pran Kishore, Curr. Top. Med. Chem., 2017, 17, 238-250.

17 V. Sharma and V. Kumar, Med. Chem. Res., 2014, 23, 35933606.

18 S. Cherukupalli, R. Karpoormath, B. Chandrasekaran, G. A. Hampannavar, N. Thapliyal and V. N. Palakollu, Eur. J. Med. Chem., 2017, 126, 298-352.

19 S. El Kazzouli, J. Koubachi, N. El Brahmi and G. Guillaumet, RSC Adv., 2015, 5, 15292-15327.

20 K. Pericherla, P. Kaswan, K. Pandey and A. Kumar, Synthesis, 2015, 47, 887-912.

21 C. R. G. A. C. de Souza, M. F. Z. J. Amaral, A. A. Dos Santos and G. C. Clososki, Targets Heterocycl. Syst., 2016, 20, 365392.

22 M. A. Salem, M. H. Helal, M. A. Gouda, H. H. Abd El-Gawad, M. A. M. Shehab and A. El-Khalafawy, Synth. Commun., 2019, 49, 1750-1776.

23 I. Kim, S. H. Kim, Korea Patent, KR20160006050 A, 2016-0118.

24 S. Park, Y. Jung and I. Kim, Tetrahedron, 2014, 70, 75347550.

25 D. K. Singh and I. Kim, ARKIVOC, 2019, (part iii), 8-21.

26 J. Kim, M. Park, J. Choi, D. K. Singh, H. J. Kwon, S. H. Kim and I. Kim, Bioorg. Med. Chem. Lett., 2019, 29, 1350-1356.

27 A. Dagar, G. H. Bae, J. H. Lee and I. Kim, J. Org. Chem., 2019, 84, 6916-6927.

28 S. Ramesh, S. Kr Ghosh and R. Nagarajan, Org. Biomol. Chem., 2013, 11, 7712-7720. 
29 L. F. Tietze, H. P. Bell and S. Chandrasekhar, Angew. Chem., Int. Ed. Engl., 2003, 42, 3996-4028.

30 V. V. Kouznetsov and A. Gomez-Barrio, Eur. J. Med. Chem., 2009, 44, 3091-3113.

31 K. Nepali, S. Sharma, M. Sharma, P. M. Bedi and K. L. Dhar, Eur. J. Med. Chem., 2014, 77, 422-487.

32 Shaveta, S. Mishra and P. Singh, Eur. J. Med. Chem., 2016, 124, 500-536.

33 M. Kim, Y. Jung and I. Kim, J. Org. Chem., 2013, 78, 1039510404.
34 B. Trofimov, A. Ivanov, E. Skital'tseva, A. Vasil'tsov, I. Ushakov, K. Petrushenko and A. b. Mikhaleva, Synthesis, 2009, 3603-3610.

35 S. Banerjee, A. K. Both and M. Sarkar, ACS Omega, 2018, 3, 15709-15724.

36 S. Choi, J. Bouffard and Y. Kim, Chem. Sci., 2014, 5, 751-755.

37 X. Cao, L. Meng, Z. Li, Y. Mao, H. Lan, L. Chen, Y. Fan and T. Yi, Langmuir, 2014, 30, 11753-11760.

38 Y. Shen, H. Liu, J. Cao, S. Zhang, W. Li and B. Yang, Phys. Chem. Chem. Phys., 2019, 21, 14511-14515. 